Fidan, M. ve Yılmaz, A. (2021). Bilinmeyen kelimelerin öğretiminde kullanılan yöntemlerin etkililiğinin öğrencilerin görüşleri vasıtasıyla değerlendirilmesi. Ana Dili Eğitimi Dergisi, 9(2), 395-415.

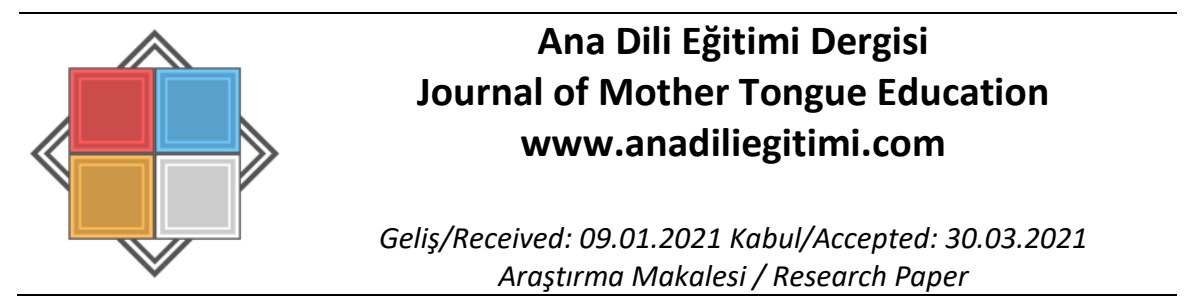

\title{
Bilinmeyen Kelimelerin Öğretiminde Kullanılan Yöntemlerin Etkililiğinin Öğrencilerin Görüşleri Vasıtasıyla Değerlendirilmesi
}

\begin{abstract}
Mehmet FIDAN*
Ahmet YILMAZ**

Öz

Öğrencilerin anlama becerilerinin geliştirilmesinde metnin içeriğinin doğru olarak anlaşılmasının önemli rolü vardır. Bu süreçte metinde bulunan söz varlığına öğrencinin hâkim olması etkili/doğru anlamayı da beraberinde getirecektir. Sıralanan bu özellikler bilinmeyen kelimelerin öğretiminde kullanılan yöntemlerin etkililiğinin araştııımasını gerektirmektedir. Bu araştırmanın amacı bilinmeyen kelimelerin öğretiminde kullanılan yöntemlerin etkililiğinin değerlendirilmesidir. Araştırmanın çalışma grubu altıncı ve yedinci sınıf öğrencilerinden oluşmuştur. Karma yöntemin uygulandığı bu araştırmada tarama modeli ve betimsel analiz kullanılmışıı. Öğrencilerin Türkçe derslerindeki bilinmeyen kelimelerin öğretiminde kullanılan yöntemlere yönelik tutumlarının belirlenebilmesi için likert tipi tutum ölçeği kullanılmıştır. Burada elde edilen veriler frekans/yüzdelik dilim ve t-testi ile analiz edilmiştir. Açık uçlu soruların yer aldığı formlardan elde edilen sonuçlar doküman incelemesi yöntemi ve betimsel analiz yöntemleri vasıtasıyla yorumlanmıştır. Araştırmada elde edilen verilere göre öğrencilerin bilinmeyen kelimelerin öğretiminde kullanılan yöntemleri genel olarak olumlu şekilde niteledikleri görülmüştür. Ayrıca bilinmeyen kelimelerin öğretim süreçlerinde sınıf düzeyi, cinsiyet değişkenlerinin bazı konu alanlarında $p<0,05$ düzeyinde anlamlı farklılık oluşturduğu tespit edilmiştir.
\end{abstract}

Anahtar Kelimeler: Kelime hazinesi, bilinmeyen kelimelerin öğretimi, bağlamdan hareketle tahmin

\section{Evaluating the Effectiveness of the Methods Used in Teaching Unknown Words Through Students' Views}

\begin{abstract}
The correct understanding of the content of the text has an important role in the development of students' comprehension skills. In this process, the students know of the vocabulary in the text will bring along effective / correct understanding. These listed features require the investigation of the effectiveness of the methods used in teaching unknown words. The aim of this research is to evaluate the effectiveness of the methods used in teaching unknown words. The study group of the research consisted of sixth and seventh grade students. Scanning model and descriptive analysis were used in this study where mixed method was used. Likert type attitude scale was used to determine the students' attitudes towards the methods used in teaching unknown words in Turkish lessons. The data obtained here were analyzed by frequency / percentile and t-test. The results obtained from the forms with open-ended questions were interpreted through the document analysis method and descriptive analysis methods. According to the data obtained in the study, it was seen that the students generally qualified the methods used in teaching unknown words in a positive way. In addition, it was determined that the variables of class level and gender
\end{abstract}

\footnotetext{
* Doç. Dr., Aksaray Üniversitesi, Eğitim Fakültesi, Türkçe ve Sosyal Bilimler Eğitimi Bölümü, Aksaray, fidanm3838@gmail.com, ORCID: orcid.org/0000-0002-9347-2992

** Öğretmen, MEB, Kayseri, ahmet.yilmaz2538@gmail.com, ORCID: orcid.org/0000-0002-4203-3367
} 
in the teaching processes of unknown words made a significant difference at $p<0.05$ level in some subject areas.

Key Words: Vocabulary, teaching unknown words, guessing from context

\section{Giriş}

Kelime öğretiminde, ana dili eğitimi ve yabancı dil eğitimi olmak üzere iki ana eğitsel sürecin bulunduğu görülür. Bu durum eğitsel süreçler sonucunda öğrencilere kazandırılması hedeflenen beceriler açısından öğretmenlerin farklı yöntemleri kullanmalarını gerektirebilmektedir. Nitekim ölçme değerlendirmenin yanında öğretim yöntemleri, araç-gereç gibi yönlerden de çeşitlilik sağlanması öğretim programlarının temel yaklaşımları arasında yer alır (MEB, 2019: 6). Öğretim yöntemleri, ölçme değerlendirme etkinlikleri konularında çeşitliliğin sağlanmasında öğrencilerin ilgi, ihtiyaç ve hazırbulunuşluklarının, sınıfın özelliklerinin, dersin kazanımlarının vb. göz önünde bulundurulması gerekmektedir. Bu doğrultuda süreçlerin yürütülmesinde özgünlük ve yaratıclık boyutunda öğretmenlere önemli sorumluluk düşmektedir (MEB, 2019: 6).

Ana dili öğretim süreçleri bireylerin dil becerilerinin gelişiminin yanında akademik becerilerinin de geliştirilmesinde önemli konumda bulunur. Çünkü dinleme/izleme ile birlikte okuma becerisi, bireylerin olayları, kavramları vb. algılamalarında/anlamalarında etkindir. Bu sebeple ana dili eğitiminin bu çok boyutlu yapısının göz önünde bulundurulması gerekir. Bu açıdan anlama becerilerinin geliştirilmesinin bireylerinin kelime hazinesi ile orantılı olduğu söylenebilir. Kelime hazinesinin bu önemli özelliğinden dolayı kelimelerin öğretiminde mantık çerçevesinin olması gerekliliği, kelimelerin anlam özellikleri üzerinde durulması zorunluluğu gibi konulara araştırmacıların dikkat çektikleri görülür (Özbay ve Melanlıŏlu, 2008a: 42).

Kelime öğretiminde kullanılan yöntemler incelendiğinde, araştırmacıların konuyu çeşitli açılardan ele aldıkları görülür. Özbay ve Melanlıoğlu (2008b: 57) kelime öğretiminde örneklemin niteliğine dikkat çeker ve Dîvânu Lugâti't-Türk'ün kelime öğretiminde kullanım örneklerine yer vermesi sebebiyle önemli konumda olduğunu vurgular. Büker ve Zeytinkaya (2013: 189) kelime öğretiminde eşzıt anlam özelliklerinin kullanılmasının faydalı olduğunu belirtir. Duran ve Bitir (2017: 70) ise bağlamdan yola çıkarak kelime öğretiminin, kelimelerin kalıcılığı yönünden olumlu etkisinin olduğunu tespit eder. Nitekim Türkçe derslerinde kelime öğretim yöntemleri ele alındığında bağlamdan yola çıkarak kelimelerin anlamlarının tahmin edilmesi tekniğinin ilgili programda kazanım olarak yer aldığı görülür:

"T.5.3.5. Bağlamdan yararlanarak bilmediği kelime ve kelime gruplarının anlamını tahmin eder.

a) Öğrencilerin tahmin ettikleri kelime ve kelime gruplarını öğrenmek için görseller, sözlük, atasözleri ve deyimler sözlüğü vb. araçları kullanmaları sağlanır. 2019: 36)

b) Öğrencinin öğrendiği kelime ve kelime gruplarından sözlük oluşturması teşvik edilir." (MEB,

Bu kazanım incelendiğinde bilinmeyen kelimelerin öğretim süreçlerinde kelimenin anlamının doğrudan öğretmen tarafından söylenilmesi ya da sözlükten bulunması gibi yöntemlerin uygun olmadığı görülür. Nitekim kazanımda bilinmeyen kelimelerin cümlenin, paragrafın bağlamından hareketle tahmin edilmesi gerekliliğine vurgu yapılmaktadır. Ayrıca burada bilinmeyen kelimelerin hatırlanmasının kolaylaştııılması amacıyla öğrencilerin sözlük oluşturmaları yönünden teşvik edilmelerinin istendiği de görülmektedir (MEB, 2019: 36). Kelime öğretim süreçlerinde öğrencilerin bağlamdan yararlanarak kelimeleri tahmin etmelerinin nispeten zor olduğu durumlarla da karşılaşmak mümkündür. Bu konuda Göçer'in (2018: 123-124) kelime öğretim süreçlerine yönelik sıralaması önemlidir. Göçer (2018: 123) ilgili kazanımla (MEB, 2019: 36) uyumlu şekilde öncelikli olarak kelimelerin bağlamdan yola çıkarak anlamlarının ne olacağı konusunda tahminde bulunulması gerektiğini, daha sonra bilinmeyen kelimenin cümleden çıkarılarak anlamda ne gibi değişmeler olduğunun ifade edilmesini önerir. Öğrencilerin bağlamdan yola çıkarak tahmin etmede zorlandıkları görüldüğünde, bu kelimenin eş-zıt anlamlıları gibi ipuçlarının verilmesini, bu sürece rağmen kelimenin anlamı bulunamamışsa en son aşamada sözlüğe başvurulması gerektiğini ifade eder (Göçer, 2018: 123). Göçer (2018: 124) ayrıca yeni kelimelerin geçtiği atasözleri, deyimlerden yararlanılması; sözlü ve yazılı anlatım uygulamalarında bu yeni kelimelerin kullanılmasına yönelik çalışmalar yapılması gerektiğini 
belirtir. Türkçe Öğretim Programı'nda da kelime öğretim süreçlerinde eş-zıt anlamlıık, eş seslilik gibi niteliklerin kazanım olarak yer aldığı görülmektedir (MEB, 2019: 36).

Öğretmenlerin ve öğrencilerin kelime öğretim süreçlerinde kullandıkları yöntemler, stratejiler öğrencilerin öğrenmelerini etkileyebilmektedir. Nitekim Erdem (2005: 6) öğrenmede başarının kullanılan strateji ile bağlantılı olduğunu belirtir. Öğrencilerin kelime öğretim süreçlerinin etkililiğinin artırılması için çeşitli araştırmaların bulunduğu görülmektedir. Bu yöndeki araştırmada Memiş (2019a: 2584-2586) geliştirdiği kelime öğretim stratejileri ölçeğinde, kelime öğrenme stratejilerini öğrenme, açıklama, pekiştirme, beceri kazandırma, yönlendirme ve kontrol stratejileri ana başlıkları altında gruplar.

Derslerde öğretim süreçlerinde kullanılan yöntem ve stratejilerin belirlenmesinde ders kitapları önemli konumda bulunur. Çünkü ders kitaplarındaki metinler ve bu metinlere yönelik etkinlikler Türkçe derslerindeki öğretim uygulamalarının genelini içerisinde barındırmaktadır. Bu durumu ders kitaplarındaki kelime hazinesi açısından ele alan Karadağ ve Kurudayıoğlu (2010: 435) Türkçe ders kitaplarında öğretilmesi hedeflenen kelimelerin sık kullanımına dikkat çeker ve bu açıdan "metinlerde bir kez tekrar edilen kelimelerinin sayısının" ders kitaplarındaki diğer kelimelere oranla düşük olması gerektiğini belirtir. Kelime öğretiminin önemli aşamalarından biri de okunulanların doğru anlaşılabilmesidir. Bu durum doğrudan sözlü anlatımda kelimelerin doğru telaffuz edilmesini de etkileyebilmektedir. Bu açıdan kelime tekrar tekniğinin "okuduğunu anlama becerilerini" ve "akıcı okumayı" olumlu yönde geliştirdiği Yılmaz (2008: 343) tarafından tespit edilmiştir.

Türkçe dersleri öğrencilerin ana dili becerilerinin geliştirilmesinde önemli görev üstlenir. Bu ders kapsamında okulda ve okul dışında yapılan etkinlikler öğrencilerin akademik becerilerinin geliştirilmesinin yanında onların hayata hazırlanmasına da imkân sağlar. Nitekim bu duruma Türkçe Öğretim Programı'nda da değinilir ve derslerin bireyleri hayata hazırlamadaki rolüne dikkat çekilir (MEB, 2019: 3). Öğrencilerin dil becerilerinin geliştirilmesinde onların kelime hazinelerinin zenginliği bu sürece doğrudan etkide bulunur. Çünkü bireyler çevrelerindeki olayları, durumları, kavramları kelime hazinelerinin yardımıyla algılar. Aynı zamanda kendilerini yazılı ve sözlü ifade edebilmelerinde de sahip oldukları kelime hazineleri, anlatımlarının içeriğinin niteliğini belirleyebilir. Bu sebeple eğitim öğretim süreçlerinde öğrencilerin söz varlığını geliştirme etkinliklerinin önemli bir rolü bulunur.

Kelime hazinesinin geliştirilmesinde -diğer dil becerilerine ek olarak- okuma becerisi alanına yönelik etkinliklerin niteliği de önemlidir. Bu konuda Aktaş ve Gündüz (2017: 41) "Sözcük dağarımızı geliştirmenin tek yolu sürekli okumaktır." diyerek okumanın kelime hazinesinin gelişimindeki konumunu açıklar. Okunan metinlerin daha iyi algılanıp çözümlenmesinde metnin söz varlığının iyi tanınmasının önemli etkisi bulunur. Bu konuda Hsueh-chao ve Nation (2000: 422) bir metinde yer alan bilinmeyen kelimelerinin yoğunluğunun o metnin anlaşıması üzerinde önemli etkisinin bulunduğunu belirtir. Bu doğrultuda Türkçe derslerindeki hemen hemen bütün metni anlama çalışmalarının başında bilinmeyen kelimelere yönelik etkinlikler gelir. Bu uygulamaların sebebinin metnin tam olarak anlaşıldığı zaman, dersin ilerleyen süreçlerinden verim alınabileceği düşüncesi olduğu söylenebilir.

Memiş (2019b: 288) yabancılara Türkçe öğretim sürecinde kullanılan kelime öğretim stratejilerini incelediği araştırmasında, öğreticilerin kelime öğretim süreçlerinde açıklama stratejilerini diğerlerine göre daha fazla; beceri kazandırma stratejilerini ise daha az kullandıklarını ifade eder. Yabancılara Türkçe öğretiminde kullanılan kelime öğrenme stratejilerine öğrenciler açısından yaklaşıldığı bir diğer araştırmada ise diğer gruplara göre daha üst seviyede dil yeterliliği olan C1 seviyesindeki öğrencilerin, kelime stratejilerini kullanım açısından puan ortalamalarının diğer seviye gruplarına göre daha düşük olduğu tespit edilmiştir (Biçer ve Polatcan, 2015: 824).

Kelime öğretim süreçlerinin geliştirilmesine ve yapılan uygulamaların etkililiğine yönelik araştırmalar incelendiğinde bazı araştırma sonuçları şu şekilde sıralanabilir: İlter (2014: 755), Frayer modelinin "kelime öğretiminde bir grafik düzenleyici" olduğunu ve öğrencilerin öğrendikleri kelimelere yeni anlamlar kazandırmalarına imkân sağladığını belirtir. İlter (2014: 764) Frayer modelinin kelime öğretim süreçlerinde kullanıımasının öğrencilerin sözcük varlığının gelişimine olumlu yönde katkılarının olacağını ifade eder. Akyüz Aru ve Ertem (2014: 675) ise inceledikleri ilkokul Türkçe ders kitaplarında, kelime öğretimi açısından "sistemli bir planlamanın olmadığını" belirtir. Kansızoğlu (2017: 835) geleneksel kelime öğretim yöntemleri olarak tanımladığı, kelimelerin liste şeklinde ezberletilmesi, 
öğrenilen kelimenin bir cümle içinde kullanılması gibi uygulamaların öğrencilerin kelime hazinesinin geliştirilmesinde yetersiz olduğunun araştırmalarla ortaya konduğunu ifade eder. ilgili çalışmaların sonuçları ele alındığında kelime öğretim süreçlerindeki uygulamaların değerlendirilmesi ve hangi yöntemlerin etkili olabileceği konusunda bilgi verildiği görülmektedir.

$\mathrm{Bu}$ araştırmanın amacı Türkçe derslerinde bilinmeyen kelimelerin öğretiminde kullanılan yöntemlerin etkililiğinin değerlendirilmesidir. Bu amaçla ortaokul öğrencilerinin Türkçe derslerinde bilinmeyen kelimelerle ilgili etkinliklere yönelik tutumlarının belirlenmesi ve bu konuda görüşlerinin alınması planlanmıştır. Öğrencilerin okudukları veya dinledikleri metinleri tam olarak algılamaları dil becerilerinin bu yöndeki gelişimine olumlu katkı sağlamaktadır. Elbette bu durumun sağlanmasında metinlerin sözcük varlığının bilinmesinin önemli rolü vardır. Ayrıca öğrencinin söz varlı̆ının zengin olması kendi düşüncelerini etkin bir şekilde ifade edebilmesine de aracı olmaktadır. Nitekim Aktaş ve Gündüz (2017: 42) okumanın zihinsel becerilerin gelişimini de sağlayacağını belirtir. Bilinmeyen kelimelere yönelik Türkçe derslerinde yapılan etkinlikler yukarıda sayılan bu özelliklerden dolayı üzerinde önemle durulması gereken konulardandır. Bu sebeple araştırmamızda öğrencilerin bilinmeyen kelimelere yönelik tutum ve görüşlerinin belirlenmesi hedeflenmiştir. Bu niteliklerin belirlenmesinin Türkçe derslerinde kelime öğretimine yönelik etkinliklerin geliştirilmesi sürecine olumlu yönde katkı sunacağı beklenmektedir. Bu doğrultuda araştırma sonuçlarının alan uzmanlarına ve öğretmenlere sözcük öğretiminde yöntem konusunda katkı sağlaması hedeflenmektedir. Öğrencilerin araştırma sırasında soruları tam ve doğru olarak cevapladıkları; akran, çevre gibi değişkenlerden etkilenmedikleri varsayılmaktadır.

Bu araştırmada cevapları aranan sorular şu şekilde özetlenebilir:

1. Öğrencilerin tutum ölçeğindeki maddelere verdikleri cevapların aritmetik oranları (frekansyüzde) nedir?

2. Öğrencilerin verdikleri cevaplar sınıf düzeyi değişkeni yönünden farklılaşmakta mıdır?

3. Öğrencilerin verdikleri cevaplar cinsiyet değiş̧eni yönünden farklılaşmakta mıdır?

4. Öğrencilerin açık uçlu görüşme formundaki verdikleri cevaplar ile tutum ölçeği arasında benzerlik ve farklılıklar var mıdır?

\section{Araştırmanın Modeli}

\section{Yöntem}

Karma yöntemle tasarlanan bu araştırmada nicel yöntemlerden tarama modeli kullanılmıştır. Özellikle betimleme yapabilmek amacıyla görüş, ilgi vb. yönlerden bilgi alınan katılımcıların sayısının fazla olması tarama modelinin temel niteliklerindendir (Büyüköztürk, Kılıç Çakmak, Akgün, Karadeniz ve Demirel, 2019: 184). Bu çalışmada nitel araştırma yöntemlerinden durum çalışması kullanıımıştır. Yıldırım ve Şimşek (2008: 77) durum çalışmasının derinliğine araştırma yapılmasına ve konuya bütüncül yaklaşılmasına imkân sağladığını belirtir. Bu doğrultuda araştırmada Türkçe derslerindeki bilinmeyen kelimelerin öğretiminde kullanılan yöntemlerin etkililiği belirlenmeye çalışımıştır.

\section{Örneklem / Araştırma grubu}

Bu araştırmanın evreni ortaokul öğrencilerinden oluşmuştur. Araştırmada örneklem seçiminde seçkisiz (random) örnekleme yöntemi kullanılmıştır. Büyüköztürk, Kılıç Çakmak, Akgün, Karadeniz, Demirel (2019: 88) seçkisiz örnekleme yönteminin evrenin temsilini sağlamada diğer örnekleme yöntemlerine göre daha güçlü olduğunu ifade ederler. Araştırmanın örneklemi (araştırma grubu) ise ortaokul 6. ve 7. sınıf öğrencilerinden oluşmuştur. Bu sınıf düzeylerinin seçilmesinin sebebi şu şekildedir: Bu araştırmada bir önceki eğitim öğretim yılında yapılan bilinmeyen kelimelere yönelik etkinliklerin öğrenciler tarafından değerlendirilmesi amaçlanmıştır. Çünkü bu vasıta ile öğrencilerin yıl boyunca yapılan etkinlik ve uygulamalara yönelik bilgi ve deneyim sahibi oldukları düşünülmektedir. Bu amaçla 2019-2020 Eğitim Öğretim Yılı'nda 5. ve 6. sınıflarda bulunup, 2020-2021 Eğitim Öğretim Yılı'nda 6. ve 7. sınıfa geçen öğrenciler araştırma grubu olarak belirlenmiştir. Ayrıca bu sınıf düzeylerinin belirlenmesinde 8. sınıfların seçilmemesinin sebebi ortaokul eğitimlerinin son yılında olan bu öğrencilerin diğer sınıflara nispeten derslerinin daha yoğun olduğu yönündeki düşüncedir. Bu doğrultuda araştırma 2020-2021 Eğitim Öğretim yılında Kayseri ili Kocasinan illçesi'nde yer alan bir 
ortaokuldaki 6. ve 7. sınıf öğrencilerinin katılımı ile uygulanmıştır. Araştırmaya toplamda 120 öğrenci katılmıştır. Öğrenci gruplarının dağılımına yönelik veriler aşağıda verilmiştir:

Tablo 1.

Tutum ölçeği / Sınıflara göre katııımcıların dağı̆ımı

\begin{tabular}{clc} 
Sınıf & Frekans & Yüzde \\
\hline 6 & 52 & 52,0 \\
7 & 48 & 48,0 \\
Total & 100 & 100,0 \\
\hline
\end{tabular}

Tablo 2.

Cinsiyete göre katılımcıların dağılımı

\begin{tabular}{llc} 
Cinsiyet & Frekans & Yüzde \\
\hline Kız & 52 & 52,0 \\
Erkek & 48 & 48,0 \\
Toplam & 100 & 100,0 \\
\hline
\end{tabular}

Tablo 3.

Açık uçlu görüşmeye ait dağılım

\begin{tabular}{llc} 
Sınıf & Frekans & Yüzde \\
\hline 6 & 10 & 50,0 \\
7 & 10 & 50,0 \\
Total & 100 & 100,0 \\
\hline
\end{tabular}

Öğrencilerin araştırmaya katılımında gönüllük ilkesi esas alınmıştır. Araştırmaya dair detaylı açıklamalar yapılarak, öğrencilere istedikleri takdirde araştırmaya katılmayacakları ve katılsalar dahi istedikleri anda araştırmadan ayrılabilecekleri yazılı olarak belirtilmiştir. Araştırmada tutum ölçeği ve standartlaştırılmış açık uçlu görüşme formu kullanılmıştır. Tutum ölçeği ile yapılan araştırmaya 100 öğrenci, açık uçlu görüşmeyle yapılan araştırmaya ise 20 öğrenci katılmıştır.

\section{Veri Toplama Araçları}

Bu araştırmada tutum ölçeği ve açık uçlu görüşme formları vasıtasıyla veriler elde edilmiştir. Bu doğrultuda araştırmada kullanılan ölçeklerin hazırlanması aşamasında, Türkçe derslerinde bilinmeyen kelimelerin öğretimine yönelik etkinliklerdeki kullanılan yöntemler belirlenmeye çalışılmıştır. Öncelikli olarak ilgili konuda veri toplanması amaçlanan sınıf düzeylerinde bilinmeyen kelimelerin öğretiminde hangi yöntemlerin kullanıldı̆̆ının belirlenmesi amacıyla Türkçe ders kitapları incelenmiştir. Çünkü derslerin yürütülmesinde temel kaynak olarak kullanılan ders kitaplarının önemli yönlendirici etkisi bulunmaktadır. Bu amaçla 2019-2020 Eğitim Öğretim Yılı'nda okutulan beşinci ve altıncı sınıf Türkçe Ders Kitaplarındaki (Çapraz Baran ve Diren, 2019; Demirel, 2019) bilinmeyen kelimelere yönelik etkinlikler, kullanılan yöntemler yönünden değerlendirilmiştir. Etkinliklerde kelimelerin öğretiminde kullanılan yöntemler bu vasıta ile belirlenmiştir. Bu tespitler araştırmadaki ölçeklerde kullanılan maddelerin ve soruların oluşturulmasına yardımcı olmuştur. Araştırmacılar tarafından ölçeklerde yer verilmek üzere oluşturulan madde ve sorular 3 Türkçe öğretmenine gönderilerek görüşleri alınmıştır. Türkçe öğretmenleri bilinmeyen kelimelerin öğretimi süreçlerindeki uygulamalarına göre maddeleri ve soruları değerlendirmiştir. Türkçe öğretmenleri derslerdeki uygulamaları ile ölçekte bulunan ifadelerin uygun olduğu yönünde görüş belirtmiştir. Bu doğrultuda ölçeklerin ulaşılmak istenen bilgiler yönünden uygun olduğu sonucuna ulaşıımıştır. 
Aşağıdaki bölümde araştırma sürecinde kullanılan formlarda yer alan ifadeler ve sorular bulunmaktadır:

\section{Tutum ölçeğinde yer alan ifadeler}

1. Türkçe derslerinde okuduğumuz veya dinlediğimiz bir metindeki bilinmeyen kelimelere yönelik etkinliklerde, kelimenin sözlükteki açıklamasıyla eşleştirme yaptığımızda daha iyi öğreniyorum.

2. Türkçe derslerinde okuduğumuz veya dinlediğimiz bir metindeki bilinmeyen kelimelere yönelik etkinliklerde, kelimenin sözlükteki açıklaması verilip cevabını bulmacada aradığımızda daha iyi öğreniyorum.

3. Türkçe derslerinde okuduğumuz veya dinlediğimiz bir metindeki bilinmeyen kelimeleri sözlükten bulduğumda daha iyi öğreniyorum.

4. Türkçe derslerinde okuduğumuz veya dinlediğimiz bir metindeki bilinmeyen kelimeleri, metinde bulundukları yerdeki anlamlarını tahmin edip daha sonra da tahminimin doğruluğunu sözlükte kontrol ettiğimde daha iyi öğreniyorum.

5. Türkçe derslerinde okuduğumuz veya dinlediğimiz bir metindeki bilinmeyen kelimeleri öğretmenime sorup cevap aldığımda daha iyi öğreniyorum.

6. Türkçe derslerinde okuduğumuz veya dinlediğimiz bir metindeki bilinmeyen kelimelerle ilgili konuşma yaptığım zaman daha iyi öğreniyorum.

7. Türkçe derslerinde okuduğumuz veya dinlediğimiz bir metindeki bilinmeyen kelimelerle ilgili yazı yazdığımda (kompozisyon, şiir vb.) daha iyi öğreniyorum.

8. Türkçe derslerinde okuduğumuz veya dinlediğimiz bir metindeki bilinmeyen kelimelerle ilgili drama, canlandırma gibi oyunlar oynadığımızda daha iyi öğreniyorum.

9. Türkçe derslerinde okuduğumuz veya dinlediğimiz bir metindeki bilinmeyen kelimeleri ve açıklamalarını kaydettiğim bir sözlüğüm vardır.

10.Bu sözlüğüme yeni öğrendiğim bütün kelimeleri kaydederim.

11.Bu sözlüğüme yeni öğrendiğim kelimelerden ilgimi çekenleri kaydederim.

12.Bu sözlüğüme yeni öğrendiğim kelimelerden ileride faydalanacağımı düşündüklerimi kaydederim.

13.Türkçe derslerinde okuduğumuz veya dinlediğimiz metinler aracılığıyla öğrendiğim kelimelerle daha önce de karşılaşmıştım. Ancak bu kelimelerin manalarını bilmiyordum.

14.Türkçe derslerinde okuduğumuz veya dinlediğimiz metinler aracılığıyla öğrendiğim kelimelerle diğer derslerde de (matematik, müzik, sosyal bilgiler vb.) karşılaşırım.

15.Türkçe derslerinde okuduğumuz veya dinlediğimiz metinler aracılığıyla öğrendiğim kelimeleri diğer derslerde (matematik, müzik, sosyal bilgiler vb.) de kullanırım.

16.Türkçe derslerinde okuduğumuz veya dinlediğimiz bir metindeki bilinmeyen kelimelere yönelik etkinliklerin benim sözcük hazinemin gelişmesine katkısının olduğunu düşünüyorum.

17.Türkçe derslerinde okuduğumuz veya dinlediğimiz metinler aracılığıyla öğrendiğim kelimeler Türkçe dersindeki diğer metinlerde de yer alır.

18.Türkçe derslerinde okuduğumuz veya dinlediğimiz metinler aracıllğıyla öğrendiğim kelimelerle günlük yaşantımda (büyüklerin konuşmalarında, gazete ve dergilerde, TV'de, İnternette vb.) karşılaşırım.

19.Türkçe derslerinde okuduğumuz veya dinlediğimiz metinler aracılığıyla öğrendiğim kelimeleri günlük yaşantımda genellikle ben de kullanmaya çalışııım

20.Türkçe derslerinde okuduğumuz veya dinlediğimiz metinlerdeki bilinmeyen kelimelere yönelik ders kitaplarındaki etkinliklerin yeterli olduğunu düşünüyorum.

\section{Açık uçlu görüşme formunda yer alan sorular}

1. Size göre Türkçe derslerinde metinlerde yer alan bilinmeyen kelimeleri öğrenmek için en iyi yöntem ne olabilir? Açıklayınız.

2. Türkçe derslerinde okuduğunuz veya dinlediğiniz metinler aracılığıyla öğrendiğiniz kelimeleri diğer derslerinizde de kullandınız mı? Cevabınız evet ise hangi dersler olduğunu açıklayınız? 
3. Türkçe derslerinde okuduğunuz veya dinlediğiniz metinler aracıllğıyla öğrendiğiniz kelimeler günlük yaşantınızda size katkı sağladı mı? Açıklayınız.

4. Türkçe derslerinde iyi öğrendiğinizi düşündüğünüz kelimelerle ilgili derslerde hangi türden etkinlikleri yaptığınızı hatırlıyorsanız açıklayınız.

\section{Geçerlik ve Güvenirlik}

$\mathrm{Bu}$ araştırmada nicel verilerin elde edilmesinde tutum ölçeği kullanılmıştır. Ölçekteki maddelerin cevapları kesinlikle katılıyorum, katılıyorum, kararsızım, katılmıyorum, kesinlikle katılmıyorum şeklindedir. Elde edilen veriler Spss 20 programı vasıtası ile puanlanmıştır. Bu puanlama şu şekildedir:

Kesinlikle katılıyorum:5, Katılıyorum: 4, Kararsızım: 3, Katılmıyorum: 2, Kesinlikle katılmıyorum:

1

Araştırmada konu alanına yönelik öğrencilerin tutumlarının belirlenebilmesi için ölçek hazırlanmıştır. Ölçeğin hazırlanması aşamasında öncelikle uzman görüşleri doğrultusunda sorular oluşturulmuştur. Çeşitli kurumlarda (MEB, Aksaray Üniversitesi) bulunan 3 uzmandan soruların araştırmanın amacına yönelikliği konusunda değerlendirme yapmaları istenmiştir. Uzman görüşleri doğrultusunda bazı soruların içeriği düzenlenmiştir. Uygulanan ölçeğin geçerlilik ve güvenilirlik yönünün tespit edilebilmesi için 40 öğrenciye ön test uygulanmıştır. Ölçek sorularını yanıtlamada katılımcıların gönüllüğü esas alınmıştır. Bu durum (katılımcıların gönüllüğü) sadece ön test aşamasında değil araştırmanın bütün aşamalarında göz önünde bulundurulmuştur. Ön test aşamasında elde edilen veriler ile ölçeğin alfa kat sayısı değeri belirlenmiştir. Bademci (2006: 438), Kula Kartal ve Mor Dirlik (2016: 1869) Cronbach alfa kat sayısı değerinin ölçeklerin güvenilirliğinin tespit edilmesinde kullanıldığını belirtirler. Bu doğrultuda yapılan analiz sonucunda alfa kat sayısı değeri ,871 olarak tespit edilmiştir. Bu sonuçlar Tablo 1'de yer almaktadır.

Tablo 4.

Alfa kat sayısı

\begin{tabular}{cc}
\hline Cronbach's Alpha Based on Standardized Items & N of Items \\
\hline, 871 & 20 \\
\hline
\end{tabular}

Tablo 4'te görüldüğü üzere alfa kat sayısı değeri 0,871 olarak tespit edilmiştir. Kayış'a (2010: 405) göre alfa kat sayısı değeri “ $0.60 \leq \alpha<0.80$ ” arası olduğunda oldukça güvenilirliği, “ $0.80 \leq \alpha<1.00$ ” arası olduğunda ise yüksek güvenilirliği göstermektedir. Elde edilen bu sonuçlara göre hazırlanan ölçeğin yüksek güvenilirliğe sahip olduğu söylenebilir.

Tablo 5.

Faktör Analizi

Kaiser-Meyer-Olkin Measure of Sampling Adequacy.

Bartlett's Test of Sphericity Approx. Chi-Square

556,102

Df

Sig.

, 000

Alfa kat sayısı değerinin hesaplanmasının ardından aynı katılımcıların olduğu ölçeğe faktör analizi yapılmıştır. Faktör analizi değişkenlerin sınıflandırılması amacıyla da kullanılabilmektedir (Kalaycı, 2010: 321). Bu amaçla yapılan analizde KMO değeri Tablo 5'te görüldüğü üzere ,631 olarak tespit edilmiştir. KMO değerinin 0,5'in üzerinde olması gerekmektedir (Kalaycı, 2010: 322). Bu özelliği ile KMO değerinin faktör analizi için kabul edilebilir olduğu görülmektedir $(, 631>0,5)$. Araştırmada uygulanan faktör analizi sonucunda ölçekte yer alan maddelerin toplamda 5 faktör grubu oluşturduğu görülmüştür. Bu 5 faktör toplam varyansın \%75,930'unu açıklamaktadır. Birinci faktörün 8, ikinci 
faktörün 3, üçüncü faktörün 2, dördüncü faktörün 4 ve beşinci faktörün 3 maddeden oluştuğu tespit edilmiştir.

\section{Verilerin Analizi}

Araştırmada nicel ve nitel araştırma yöntemleri bir arada kullanılmıştır. Öğrencilerin Türkçe derslerindeki bilinmeyen kelimelerin öğretiminde kullanılan yöntemlere yönelik tutumlarının belirlenebilmesi için likert tipi tutum ölçeği kullanılmıştır. Bu ölçekte yer alan maddeleri toplamda 100 öğrenci cevaplamıştır. Bu ölçeğe ait veriler Spss 20 programı ile analiz edilmiştir. Ölçekte bulunan maddelere verilen cevaplar yüzdelik oran yönünden analiz edilmiştir. Ayrıca sorulara verilen cevapların sınıf düzeyi ve cinsiyet yönünden farklılık oluşturup oluşturmadığı da incelenmiştir.

Araştırmada standartlaştırılmış açık uçlu görüşme formunda yer alan soruları toplamda 20 öğrenci cevaplamıştır. Araştırmada veri toplama metodu olarak doküman incelemesi kullanılmıştır. Doküman incelemesi "araştırılması hedeflenen olgu ve olgular hakkında bilgi içeren yazııı materyallerin analizinde" kullanışlı bir yöntem olarak ön plana çıkmaktadır (Yıldırım ve Şimşek, 2008: 187). Bu araştırmada elde edilen verilerin analizinde betimsel analiz metodundan yararlanılmıştır. Betimsel analiz yönteminde değerlendirme yaparken daha önceden belirlenen temalara göre yorumlama yapılmaktadır (Yıldırım ve Şimşek, 2008: 224). Bu araştırmadaki formlarda yer alan soruların her biri tema alanı olarak belirlenmiştir.

Araştırmada kullanılan ölçeklerin oluşturulması aşamasında 2019-2020 Eğitim Öğretim Yılı'nda okutulan beşinci ve altıncı sınıf Türkçe Ders Kitaplarındaki (Çapraz Baran ve Diren, 2019; Demirel, 2019) bilinmeyen kelimelere yönelik etkinlikler incelenmiştir. Etkinliklerde kelimelerin öğretiminde kullanılan yöntemler bu vasıta ile belirlenmiştir. Bu durum araştırma formlarında kullanılan soruların oluşturulmasına katkı sağlamıştır. Ayrıca araştırma ölçeği 3 Türkçe öğretmenine gönderilerek görüşleri alınmış ve onlardan derslerdeki uygulamalarına göre ölçeği değerlendirmeleri istenmiştir. Bu doğrultuda ölçeklerin ulaşılmak istenen bilgiler yönünden uygun olduğu tespit edilmiştir.

Araştırma sırasında öğrencilerin maddelere verdikleri cevapların oranları aritmetik ortalama değer üzerinden hesaplanarak yorumlanmıştır. Bu aşamada maddelere verilen cevapların en yüksek frekans ve yüzdelik dilimleri değerlendirilmiştir. Ayrıca sınıf düzeyi ve cinsiyet değişkenleri yönünden öğrencilerin maddelere verdikleri cevaplar bağımsız örneklemler T-testi ile ölçülmüş ve sonuçlar yorumlanmıştır. Bu aşamada çıkan sonuçlardan \%95 güven aralığında $p<0,05$ 'ten küçük (Ak, 2010: 81) yani anlamlı farklılık oluşturan maddeler değerlendirilmiştir.

Açık uçlu soruların yer aldığı formlardan elde edilen sonuçlar doküman incelemesi yöntemi ve betimsel analiz yöntemleri vasıtasıyla yorumlanmıştır. Açık uçlu formların verileriyle anketten elde edilen veriler karşılaştırılmıştır. Bu amaçla hem daha detaylı bilgi edinilmesi hem de çıkan sonuçlar arasındaki uyumun kontrol edilmesi amaçlanmıştır. Bu formların değerlendirilmesi aşamasında herhangi bir değişkenlik durumu aranmamıştır. Araştırmada öğrencilerin sorulara verdikleri cevaplar değerlendirilirken birden fazla alana yönelik cevapların da bulunduğu görülmüştür. Örneğin öğrenci Türkçe derslerinde öğrendiği yeni kelimeleri Fen bilimleri, Sosyal bilgiler, Matematik derslerinde kullandığını belirtmiştir. Bu sebeple öğrencinin cevabına 3 alanda da yer verilmiştir. Bu doğrultuda öğrenci sayısı ile verilen cevaplar doğrultusunda oluşan alanlar açısından sayısal farklılıklar oluşmuştur. Verilerin değerlendirilmesi aşamasında öğrencilerin verdikleri cevaplarda dikkat çektikleri alanlar belirlenmiştir. Öğrencilerin cevaplarında bu alanlara değinme durumları frekans (F) şeklinde ifade edilmiştir. Araştırmadaki değerlendirmelerde "öğrenci" ifadesi ile belirtilmek istenen grup, araştırmaya katılan öğrencilerdir.

\section{Araştırma ve Yayın Etiği}

Bu çalışmada "Yükseköğretim Kurumları Bilimsel Araştırma ve Yayın Etiği Yönergesi" kapsamında uyulması belirtilen tüm kurallara uyulmuştur. Yönergenin ikinci bölümü olan "Bilimsel Araştırma ve Yayın Etiğine Aykırı Eylemler" başlığı altında belirtilen eylemlerden hiçbiri gerçekleştirilmemiştir. 


\section{Etik Kurul izni}

Kurul adı = Kayseri II Milli Eğitim Müdürlüğü

Karar tarihi $=13.08 .2020$

Belge sayı numarası 10587341

\section{Bulgular}

Tutum ölçeğine yönelik bulgular - ortalama değerler

Araştırmada sürecinde kullanılan likert tipi tutum ölçeği vasıtasıyla elde edilen verilerden oluşturulmuş frekans ve aritmetik ortalama değerlerine ait Tablo 6 aşağıda yer almaktadır. Tabloda araştırmaya katılan öğrencilerin en yüksek frekans/yüzde ile cevap verdikleri ifadeler yorumlanmıştır.

Tablo 6.

Maddelere verilen cevapların ortalamaları

\begin{tabular}{|c|c|c|c|c|c|c|c|c|c|c|}
\hline \multirow{2}{*}{$\begin{array}{l}\text { Madde } \\
1\end{array}$} & \multicolumn{2}{|c|}{$\begin{array}{l}\text { Frekans \% } \\
\text { K. Katılmıyorum }\end{array}$} & \multicolumn{2}{|c|}{$\begin{array}{l}\text { Frekans \% } \\
\text { Katılmıyorum }\end{array}$} & \multicolumn{2}{|c|}{$\begin{array}{l}\text { Frekans \% } \\
\text { Kararsızım }\end{array}$} & \multicolumn{2}{|c|}{$\begin{array}{l}\text { Frekans \% } \\
\text { Katılıyorum }\end{array}$} & \multicolumn{2}{|c|}{$\begin{array}{l}\text { Frekans \% } \\
\text { K. Katılıyorum }\end{array}$} \\
\hline & 5 & 5,0 & 5 & 5,0 & 11 & 11,0 & 39 & 39,0 & 40 & 40,0 \\
\hline 2 & 5 & 5,1 & 7 & 7,1 & 8 & 8,1 & 38 & 38,4 & 41 & 41,4 \\
\hline 3 & 5 & 5,0 & 9 & 9,0 & 23 & 23,0 & 30 & 30,0 & 33 & 33,0 \\
\hline 4 & 8 & 8,0 & 7 & 7,0 & 19 & 19,0 & 31 & 31,0 & 35 & 35,0 \\
\hline 5 & 7 & 7,1 & 6 & 6,1 & 23 & 23,2 & 26 & 26,3 & 37 & 37,4 \\
\hline 6 & 14 & 14,0 & 12 & 12,0 & 16 & 16,0 & 34 & 34,0 & 24 & 24,0 \\
\hline 7 & 19 & 19,0 & 14 & 14,0 & 21 & 21,0 & 22 & 22,0 & 24 & 24,0 \\
\hline 8 & 13 & 13,1 & 12 & 12,1 & 17 & 17,2 & 24 & 24,2 & 33 & 33,3 \\
\hline 9 & 23 & 23,0 & 18 & 18,0 & 12 & 12,0 & 18 & 18,0 & 29 & 29,0 \\
\hline 10 & 23 & 23,0 & 18 & 18,0 & 26 & 26,0 & 16 & 16,0 & 17 & 17,0 \\
\hline 11 & 24 & 24,5 & 28 & 28,6 & 15 & 15,3 & 11 & 11,2 & 20 & 20,4 \\
\hline 12 & 25 & 25,3 & 21 & 21,2 & 12 & 12,1 & 14 & 14,1 & 27 & 27,3 \\
\hline 13 & 16 & 16,0 & 14 & 14,0 & 19 & 19,0 & 29 & 29,0 & 22 & 22,0 \\
\hline 14 & 7 & 7,0 & 10 & 10,0 & 17 & 17,0 & 29 & 29,0 & 37 & 37,0 \\
\hline 15 & 7 & 7,0 & 3 & 3,0 & 19 & 19,0 & 32 & 32,0 & 39 & 39,0 \\
\hline 16 & 10 & 10,0 & 2 & 2,0 & 5 & 5,0 & 26 & 26,0 & 57 & 57,0 \\
\hline 17 & 6 & 6,0 & 12 & 12,0 & 12 & 12,0 & 43 & 43,0 & 27 & 27,0 \\
\hline 18 & 5 & 5,0 & 11 & 11,0 & 17 & 17,0 & 31 & 31,0 & 36 & 36,0 \\
\hline 19 & 5 & 5,0 & 9 & 9,0 & 28 & 28,0 & 24 & 24,0 & 34 & 34,0 \\
\hline 20 & 11 & 11,0 & 17 & 17,0 & 20 & 20,0 & 32 & 32,0 & 20 & 20,0 \\
\hline
\end{tabular}

Araştırmada kullanılan ölçeğin ilk maddesi olan "Türkçe derslerinde okuduğumuz veya dinlediğimiz bir metindeki bilinmeyen kelimelere yönelik etkinliklerde, kelimenin sözlükteki açıklamasıyla eşleştirme yaptığımızda daha iyi öğreniyorum." ifadesi incelendiğinde öğrencilerin \% 5’i kesinlikle katılmıyorum, \% 5'i katılmıyorum, \% 11'i kararsızım, \% 39'u katılıyorum ve \% 40'ı tamamen katılıyorum cevabını vermiştir. Bu sonuçlara göre araştırmaya katılan öğrencilerin büyük çoğunluğunun (\% 79) bilinmeyen kelimelerin öğretiminde eşleştirme etkinliklerini olumlu olarak değerlendirdikleri söylenilebilir.

İkinci madde olan "Türkçe derslerinde okuduğumuz veya dinlediğimiz bir metindeki bilinmeyen kelimelere yönelik etkinliklerde, kelimenin sözlükteki açıklaması verilip cevabını bulmacada aradığımızda daha iyi öğreniyorum." ifadesi incelendiğinde öğrencilerin \% 5,1'i kesinlikle katılmıyorum, \% 7,1'i katılmıyorum, \% 8,1'i kararsızım, \% 38,4'ü katılıyorum ve \% 41,4'ü tamamen katılıyorum cevabını vermiştir. Bu sonuçlara göre araştırmaya katılan öğrencilerin büyük çoğunluğunun $(\% 79,8)$ bilinmeyen kelimelerin öğretiminde bulmaca türünden etkinlikleri olumlu olarak değerlendirdikleri söylenilebilir.

Üçüncü madde olan "Türkçe derslerinde okuduğumuz veya dinlediğimiz bir metindeki bilinmeyen kelimeleri sözlükten bulduğumda daha iyi öğreniyorum." ifadesi incelendiğinde 
öğrencilerin \% 5'i kesinlikle katılmıyorum, \% 9'u katılmıyorum, \% 23'ü kararsızım, \% 30'u katılıyorum ve \% 33'ü tamamen katılıyorum cevabını vermiştir. Bu sonuçlara göre araştırmaya katılan öğrencilerin çoğunluğunun (\% 63) bilinmeyen kelimelerin öğretiminde sözlük kullanımına yönelik etkinlikleri olumlu olarak değerlendirdikleri söylenilebilir.

Dördüncü madde olan "Türkçe derslerinde okuduğumuz veya dinlediğimiz bir metindeki bilinmeyen kelimeleri, metinde bulundukları yerdeki anlamlarını tahmin edip daha sonra da tahminimin doğruluğunu sözlükte kontrol ettiğimde daha iyi öğreniyorum." ifadesi incelendiğinde öğrencilerin \% 8'i kesinlikle katılmıyorum, \% 7'si katılmıyorum, \% 19'u kararsızım, \% 31'i katılıyorum ve \% 35'i tamamen katılıyorum cevabını vermiştir. Bu sonuçlara göre araştırmaya katılan öğrencilerin genelinin (\% 66) bilinmeyen kelimelerin öğretiminde tahminlerin sözlükten kontrol edilmesine yönelik etkinlikleri olumlu olarak değerlendirdikleri söylenilebilir.

Beşinci madde olan "Türkçe derslerinde okuduğumuz veya dinlediğimiz bir metindeki bilinmeyen kelimeleri öğretmenime sorup cevap aldığımda daha iyi öğreniyorum." ifadesi incelendiğinde öğrencilerin \% 7,1'i kesinlikle katılmıyorum, \% 6,1'i katılmıyorum, \% 23,2'si kararsızım, \% 26,3'ü katılıyorum ve \% 37,4'ü tamamen katılıyorum cevabını vermiştir. Bu sonuçlara göre araştırmaya katılan öğrencilerin genelinin (\% 63,7) bilinmeyen kelimelerin öğretiminde cevapların öğretmene sorulması şeklindeki uygulamaları olumlu olarak değerlendirdikleri söylenilebilir.

Altıncı madde olan "Türkçe derslerinde okuduğumuz veya dinlediğimiz bir metindeki bilinmeyen kelimelerle ilgili konuşma yaptığım zaman daha iyi öğreniyorum" ifadesi incelendiğinde öğrencilerin \% 14'ü kesinlikle katılmıyorum, \% 12'si katılmıyorum, \% 16'sı kararsızım, \% 34'ü katılıyorum ve \% 24'ü tamamen katılıyorum cevabını vermiştir. Bu sonuçlara göre araştırmaya katılan öğrencilerin çoğunluğunun (\% 58) bilinmeyen kelimelerin öğretiminde kelimelerin konuşma etkinlikleri sırasında kullanılması şeklindeki uygulamaları olumlu olarak değerlendirdikleri söylenilebilir. Ancak burada olumsuz görüş bildiren öğrencilerin oranının da (kesinlikle katılmıyorum + katılmıyorum:\% 26) dikkate değer olduğu görülmektedir.

Yedinci madde olan "Türkçe derslerinde okuduğumuz veya dinlediğimiz bir metindeki bilinmeyen kelimelerle ilgili yazı yazdığımda (kompozisyon, şiir vb.) daha iyi öğreniyorum." ifadesi incelendiğinde öğrencilerin \% 19'u kesinlikle katılmıyorum, \% 14'ü katılmıyorum, \% 21'i kararsızım, \% 22 'si katılıyorum ve \% 24'ü tamamen katılıyorum cevabını vermiştir. Bu sonuçlara göre araştırmaya katılan öğrencilerin arasında bilinmeyen kelimelerin öğretiminde kelimelerin yazma etkinlikleri sırasında kullanılması şeklindeki uygulamaları olumlu olarak değerlendirenlerin sayısının diğer gruba göre fazla olduğu görülmektedir. Ancak burada olumsuz görüş bildiren öğrencilerin oranının da (kesinlikle katılmıyorum + katılmıyorum:\% 33) dikkate değer olduğu görülmektedir.

Sekizinci madde olan "Türkçe derslerinde okuduğumuz veya dinlediğimiz bir metindeki bilinmeyen kelimelerle ilgili drama, canlandırma gibi oyunlar oynadığımızda daha iyi öğreniyorum." ifadesi incelendiğinde öğrencilerin \% 13,1'i kesinlikle katılmıyorum, \% 12,1'i katılmıyorum, \% 17,2'si kararsızım, \% 24,2'si katılıyorum ve \% 33,3'ü tamamen katılıyorum cevabını vermiştir. Bu sonuçlara göre araştırmaya katılan öğrencilerin çoğunluğunun $(\% 57,5)$ bilinmeyen kelimelerin öğretiminde oyunlaştırmanın kullanıldığı uygulamaları olumlu olarak değerlendirdikleri söylenilebilir.

Dokuzuncu madde olan "Türkçe derslerinde okuduğumuz veya dinlediğimiz bir metindeki bilinmeyen kelimeleri ve açıklamalarını kaydettiğim bir sözlüğüm vardır." ifadesi incelendiğinde öğrencilerin \% 23'ü kesinlikle katılmıyorum, \% 18'i katılmıyorum, \% 12'si kararsızım, \% 18'i katılıyorum ve \% $29^{\prime}$ u tamamen katılıyorum cevabını vermiştir. Bu sonuçlara göre araştırmaya katılan öğrenciler arasında yeni öğrenilen kelimelerin kaydedildiği sözlüğü olanların oranı (\% 47) daha yüksek olmakla birlikte, sözlüğü olmayan öğrencilerin oranı (\% 41) da dikkate değerdir.

Onuncu madde olan "Bu sözlüğüme yeni öğrendiğim bütün kelimeleri kaydederim." ifadesi incelendiğinde öğrencilerin \% 23'ü kesinlikle katılmıyorum, \% 18'i katılmıyorum, \% 26'sı kararsızım, \% 16 'sı katılıyorum ve \% 17'si tamamen katılıyorum cevabını vermiştir. Dokuzuncu madde ile bağlantılı olan bu maddede öğrencilerin sözlüklerine kelimeleri kaydederken hangi yöntemleri tercih ettiklerini belirlemek amaçlanmıştır. Elde edilen sonuçlara göre araştırmaya katılan öğrenciler arasında yeni öğrendiği bütün kelimeleri sözlüğe kaydetmeyenlerin oranının (\% 41), kaydedenlere (\% 33) göre daha fazla olduğu görülmektedir. 
On birinci madde olan "Bu sözlüğüme yeni öğrendiğim kelimelerden ilgimi çekenleri kaydederim." ifadesi incelendiğinde öğrencilerin \% 24,5'i kesinlikle katılmıyorum, \% 28,6'sı katılmıyorum, \% 15,3'ü kararsızım, \% 11,2'si katılıyorum ve \% 20,4'ü tamamen katılıyorum cevabını vermiştir. Yeni öğrenilen kelimelerin sözlüğe kaydedilme yöntemine yönelik olan bu ifadeye öğrencilerin çoğunluğunun (\% 53,1) katılmadıkları görülmektedir.

On ikinci madde olan "Bu sözlüğüme yeni öğrendiğim kelimelerden ileride faydalanacağımı düşündüklerimi kaydederim." ifadesi incelendiğinde öğrencilerin \% 25,3'ü kesinlikle katılmıyorum, \% $21,2^{\prime}$ si katılmıyorum, \% 12,1'i kararsızım, \% 14,1'i katılıyorum ve \% 27,3'ü tamamen katılıyorum cevabını vermiştir. Bu sonuçlara göre katılmayanların oranının $(\% 46,5)$, katılanların oranından $(\% 41,4)$ daha fazla olduğu görülmektedir. Bu durumda yeni öğrenilen kelimelerin sözlüğe kaydedilmesi aşamasında, kelimenin ilgi çekicilik, ileride kullanabilme özelliklerinden ziyade başka etkenlerin daha baskın olduğu söylenebilir. Bu etkenlerin öğretmenin yönlendirmeleri, etkinlikteki yönergeler vb. şeklinde olduğu düşünülmektedir.

On üçüncü madde olan "Türkçe derslerinde okuduğumuz veya dinlediğimiz metinler aracilığıyla öğrendiğim kelimelerle daha önce de karşılaşmıştım. Ancak bu kelimelerin manalarını bilmiyordum." ifadesi incelendiğinde öğrencilerin \% 16'sı kesinlikle katılmıyorum, \% 14'ü katılmıyorum, \% 19'u kararsızım, \% 29'u katılıyorum ve \% 22'si tamamen katılıyorum cevabını vermiştir. Bu sonuçlara göre yeni öğrenilen kelimelerle daha önce karşılaşma ve manalarının bilinmesi ifadesine olumlu görüş bildirenlerin oranının (\% 51) daha fazla olduğu tespit edilmiştir.

On dördüncü madde olan "Türkçe derslerinde okuduğumuz veya dinlediğimiz metinler aracılığıyla öğrendiğim kelimelerle diğer derslerde de (matematik, müzik, sosyal bilgiler vb.) karşılaşırım." ifadesi incelendiğinde öğrencilerin \% 7'si kesinlikle katılmıyorum, \% 10'u katılmıyorum, \% 17'si kararsızım, \% 29'u katılıyorum ve \% 37'si tamamen katılıyorum cevabını vermiştir. Bu sonuçlara göre araştırmaya katılan öğrencilerin çoğunluğunun (\% 66) yeni öğrenilen kelimelerle diğer derslerde karşılaştıklarını belirttikleri görülmektedir.

On beşinci madde olan "Türkçe derslerinde okuduğumuz veya dinlediğimiz metinler aracılığıyla öğrendiğim kelimeleri diğer derslerde (matematik, müzik, sosyal bilgiler vb.) de kullanırım." ifadesi incelendiğinde öğrencilerin \% 7'si kesinlikle katılmıyorum, \% 3'ü katılmıyorum, \% 19'u kararsızım, \% 32 'si katılıyorum ve \% 39'u tamamen katılıyorum cevabını vermiştir. Bu sonuçlara göre araştırmaya katılan öğrencilerin çoğunluğunun (\% 71) yeni öğrenilen kelimeleri diğer derslerde kullandıklarını belirttikleri görülmektedir. On dördüncü madde ile on beşinci madde arasında sayısal yönden yakınlığın, öğrencilerin verdikleri cevapların güvenilirliği açısından önemli olduğu düşünülmektedir. Ayrıca bu duruma ek olarak on beşinci maddedeki sonuçlarla (\% 71) açık uçlu görüşme formunda bulunan ikinci soruya verilen cevaplar (\% 75) arasında benzerlik olduğu görülmektedir.

On altıncı madde olan "Türkçe derslerinde okuduğumuz veya dinlediğimiz bir metindeki bilinmeyen kelimelere yönelik etkinliklerin benim sözcük hazinemin gelişmesine katkısının olduğunu düşünüyorum." ifadesi incelendiğinde öğrencilerin \% 10'u kesinlikle katılmıyorum, \% 2'si katılmıyorum, \% 5'i kararsızım, \% 26'sı katılıyorum ve \% 57'si tamamen katılıyorum cevabını vermiştir. Bu sonuçlara göre araştırmaya katılan öğrencilerin büyük çoğunluğunun (\% 83) yeni öğrenilen kelimelerin sözcük hazinelerinin gelişmesine katkısının olduğunu düşündükleri görülmektedir.

On yedinci madde olan "Türkçe derslerinde okuduğumuz veya dinlediğimiz metinler aracılığıyla öğrendiğim kelimeler Türkçe dersindeki diğer metinlerde de yer alır." ifadesi incelendiğinde öğrencilerin \% 6'sı kesinlikle katılmıyorum, \% 12'si katılmıyorum, \% 12'si kararsızım, \% 43'ü katılıyorum ve \% 27'si tamamen katılıyorum cevabını vermiştir. Bu sonuçlara göre araştırmaya katılan öğrencilerin çoğunluğunun (\% 70) yeni öğrendikleri kelimelerle Türkçe dersindeki diğer metinlerde de karşılaştıklarını ifade ettikleri görülmektedir. Bu durum sözcük hazinesinin geliştirilmesinde, yeni öğrenilen kelimelerle sıklıkla karşılaştırma tekniğinin ders kitaplarında tercih edildiğini göstermektedir.

On sekizinci madde olan "Türkçe derslerinde okuduğumuz veya dinlediğimiz metinler aracılı̆̆ıla öğrendiğim kelimelerle günlük yaşantımda (büyüklerin konuşmalarında, gazete ve dergilerde, TV'de, İnternette vb.) karşılaşırım." ifadesi incelendiğinde öğrencilerin \% 5'i kesinlikle katılmıyorum, \% 11'i katılmıyorum, \% 17'si kararsızım, \% 31'i katılıyorum ve \% 36'sı tamamen 
katılıyorum cevabını vermiştir. Bu sonuçlara göre araştırmaya katılan öğrencilerin çoğunluğunun (\% 67) yeni öğrendiği kelimelerle günlük yaşantılarında karşılaştıkları görülmektedir.

On dokuzuncu madde olan "Türkçe derslerinde okuduğumuz veya dinlediğimiz metinler aracılığıyla öğrendiğim kelimeleri günlük yaşantımda genellikle ben de kullanmaya çalışırım." ifadesi incelendiğinde öğrencilerin \% 5'i kesinlikle katılmıyorum, \% 9'u katılmıyorum, \% 28'i kararsızım, \% 24'ü katılıyorum ve \% 34'ü tamamen katılıyorum cevabını vermiştir. Bu sonuçlara göre araştırmaya katılan öğrencilerin çoğunluğunun (\% 58) yeni öğrendiği kelimeleri günlük yaşantılarında kullandıklarını ifade ettikleri görülmektedir. Öğrencilerin \% 14'ü ise bu ifadeye katılmadıklarını ifade etmişlerdir. Bu sorudaki yüksek orana kıyasla görüşme formunda yer alan benzer nitelikteki üçüncü soruda, öğrencilerin tamamının yeni öğrendikleri kelimeleri günlük yaşantılarında kullandıklarını belirtikleri tespit edilmiştir.

Yirminci madde olan "Türkçe derslerinde okuduğumuz veya dinlediğimiz metinlerdeki bilinmeyen kelimelere yönelik ders kitaplarındaki etkinliklerin yeterli olduğunu düşünüyorum." ifadesi incelendiğinde öğrencilerin \% 11'i kesinlikle katılmıyorum, \% 17'si katılmıyorum, \% 20'si kararsızım, \% 32 'si katılıyorum ve \% 20'si tamamen katılıyorum cevabını vermiştir. Bu sonuçlara göre araştırmaya katılan öğrencilerin çoğunluğunun (\% 52) ders kitaplarındaki bilinmeyen kelimelere yönelik etkinleri yeterli buldukları tespit edilmiştir. Bütün bu sonuçlar bilinmeyen kelimelerin öğretiminde çeşitliliğin sağlanmasının öğrenciler üzerinde olumlu etkisinin olduğunu göstermesi açısından önemlidir.

\section{Tutum ölçeğine yönelik bulgular - sınıf değişkeni}

Araştırmaya katılan öğrencilerin verdikleri cevaplar sınıf değişkeni yönünden analiz edilmiştir. Yapılan analiz sonucunda oluşan veriler Tablo 7'de bulunmaktadır. Analiz sırasında sınıflar arasında anlamlı farklılık $(p<0,05)$ oluşan maddeler değerlendirilmiştir.

Tablo 7.

Grup istatistikleri (Sınıf)

\begin{tabular}{|c|c|c|c|c|}
\hline & Sinif & Sayı & Ort. & Sig. (2-tailed) \\
\hline \multirow[t]{2}{*}{ Soru 1} & 6 & 52 & 4,0769 & ,724 \\
\hline & 7 & 48 & 4,0000 & \\
\hline \multirow[t]{2}{*}{ Soru 2} & 6 & 51 & 3,9216 & 277 \\
\hline & 7 & 48 & 4,1667 & \\
\hline \multirow{2}{*}{ Soru 3} & 6 & 52 & 3,7308 & ,725 \\
\hline & 7 & 48 & 3,8125 & \\
\hline \multirow[t]{2}{*}{ Soru 4} & 6 & 52 & 3,5577 & ,059 \\
\hline & 7 & 48 & 4,0208 & \\
\hline \multirow[t]{2}{*}{ Soru 5} & 6 & 52 & 3,8269 & ,871 \\
\hline & 7 & 47 & 3,7872 & \\
\hline \multirow[t]{2}{*}{ Soru 6} & 6 & 52 & 3,3077 & 389 \\
\hline & 7 & 48 & 3,5417 & \\
\hline \multirow[t]{2}{*}{ Soru 7} & 6 & 52 & 3,1346 & 744 \\
\hline & 7 & 48 & 3,2292 & \\
\hline \multirow[t]{2}{*}{ Soru 8} & 6 & 51 & 3,2353 & ,033 \\
\hline & 7 & 48 & 3,8333 & \\
\hline \multirow[t]{2}{*}{ Soru 9} & 6 & 52 & 3,7115 & ,000 \\
\hline & 7 & 48 & 2,4792 & \\
\hline \multirow[t]{2}{*}{ Soru 10} & 6 & 52 & 3,3462 & ,000 \\
\hline & 7 & 48 & 2,3333 & \\
\hline \multirow[t]{2}{*}{ Soru 11} & 6 & 50 & 2,9200 & 230 \\
\hline & 7 & 48 & 2,5625 & \\
\hline \multirow[t]{2}{*}{ Soru 12} & 6 & 52 & 3,0385 & ,650 \\
\hline & 7 & 47 & 2,8936 & \\
\hline
\end{tabular}




\begin{tabular}{lllll} 
Soru 13 & 6 & 52 & 3,2115 &, 661 \\
& 7 & 48 & 3,3333 & \\
Soru 14 & 6 & 52 & 3,7115 &, 513 \\
& 7 & 48 & 3,8750 & \\
Soru 15 & 6 & 52 & 3,7500 &, 106 \\
& 7 & 48 & 4,1250 &, 244 \\
Soru 16 & 6 & 52 & 4,0385 &, 059 \\
& 7 & 48 & 4,3333 &, 198 \\
Soru 17 & 6 & 52 & 3,5192 &, 010 \\
& 7 & 48 & 3,9583 &, 081 \\
Soru 18 & 6 & 52 & 3,6731 & \\
& 7 & 48 & 3,9792 & \\
Soru 19 & 6 & 52 & 3,4423 & \\
& 7 & 48 & 4,0417 & \\
Soru 20 & 6 & 52 & 3,1154 & \\
& 7 & 48 & 3,5625 & \\
\hline
\end{tabular}

Sekizinci sorudaki "Türkçe derslerinde okuduğumuz veya dinlediğimiz bir metindeki bilinmeyen kelimelerle ilgili drama, canlandırma gibi oyunlar oynadığımızda daha iyi öğreniyorum." ifadesi incelendiğinde gruplar arasında anlamlı farklılık olduğu görülmektedir. Altıncı sınıftaki öğrencilerin cevaplarının ortalaması 3,23, yedinci sınıftaki öğrencilerin cevaplarının ortalaması ise 3,83 olarak tespit edilmiştir. Bu ortalamalar arasındaki farkın istatistiksel olarak anlamlı olup olmadığı bağımsız örneklemler için $t$ testi kullanılarak yoklanmıştır. Elde edilen değerin 0,05 düzeyinde anlamlı olduğu görülmüştür $(p<0,05)$. Bu verilere göre yedinci sınıf öğrencilerinin bilinmeyen kelimelerin öğretiminde oyunlaştırmanın kullanılması yöntemini altıncı sınıf öğrencilerine göre daha çok onayladıkları söylenilebilir.

Dokuzuncu sorudaki "Türkçe derslerinde okuduğumuz veya dinlediğimiz bir metindeki bilinmeyen kelimeleri ve açıklamalarını kaydettiğim bir sözlüğüm vardır." ifadesi incelendiğinde gruplar arasında anlamlı farklılık olduğu görülmektedir. Altıncı sınıftaki öğrencilerin cevaplarının ortalaması 3,71 , yedinci sınıftaki öğrencilerin cevaplarının ortalaması ise 2,47 olarak tespit edilmiştir. $\mathrm{Bu}$ ortalamalar arasındaki farkın istatistiksel olarak anlamlı olup olmadığı bağımsız örneklemler için $t$ testi kullanılarak yoklanmıştır. Elde edilen değerin 0,05 düzeyinde anlamlı olduğu görülmüştür $(p<0,05)$. Bu verilere göre altıncı sınıf öğrencilerinin bilinmeyen kelimelerin öğretiminde sözlük oluşturma yöntemini yedinci sınıf öğrencilerine göre daha çok kullandıklarını belirtikleri görülmektedir.

Onuncu sorudaki "Bu sözlüğüme yeni öğrendiğim bütün kelimeleri kaydederim." ifadesi incelendiğinde gruplar arasında anlamlı farklılık olduğu görülmektedir. Altıncı sınıftaki öğrencilerin cevaplarının ortalaması 3,34, yedinci sınıftaki öğrencilerin cevaplarının ortalaması ise 2,33 olarak tespit edilmiştir. Bu ortalamalar arasındaki farkın istatistiksel olarak anlamlı olup olmadığı bağımsız örneklemler için t testi kullanılarak yoklanmıştır. Elde edilen değerin 0,05 düzeyinde anlamlı olduğu görülmüştür $(p<0,05)$. Bu verilere göre altıncı sınıf öğrencilerinin yeni öğrenilen kelimelerin bütününü sözlüklerine kaydetme yönünden yedinci sınıf öğrencilerine göre ortalamalarının daha fazla olduğu söylenebilir.

On dokuzuncu sorudaki "Türkçe derslerinde okuduğumuz veya dinlediğimiz metinler aracılığıyla öğrendiğim kelimeleri günlük yaşantımda genellikle ben de kullanmaya çalışırım." ifadesi incelendiğinde gruplar arasında anlamlı farklılık olduğu görülmektedir. Altıncı sınıftaki öğrencilerin cevaplarının ortalaması 3,44 , yedinci sınıftaki öğrencilerin cevaplarının ortalaması ise 4,04 olarak tespit edilmiştir. Bu ortalamalar arasındaki farkın istatistiksel olarak anlamlı olup olmadığı bağımsız örneklemler için t testi kullanılarak yoklanmıştır. Elde edilen değerin 0,05 düzeyinde anlamlı olduğu görülmüştür $(p<0,05)$. Bu verilere göre yedinci sınıf öğrencilerinin altıncı sınıf öğrencilerine göre yeni öğrendikleri kelimeleri günlük yaşantılarında daha fazla kullandıklarını ifade ettikleri söylenebilir. 
Tutum ölçeğine yönelik bulgular - cinsiyet değişkeni

Araştırmaya katılan öğrencilerin verdikleri cevaplar cinsiyet değişkeni yönünden analiz edilmiştir. Yapılan analiz sonucunda oluşan veriler Tablo 8'de bulunmaktadır. Analiz sırasında öğrenciler arasında anlamlı farklıık $(p<0,05)$ oluşan maddeler değerlendirilmiştir.

Tablo 8.

Grup istatistikleri (Cinsiyet)

\begin{tabular}{|c|c|c|c|c|}
\hline & Sinif & Sayı & Ort. & Sig. (2-tailed) \\
\hline \multirow[t]{2}{*}{ Soru 1} & $\mathrm{KIz}$ & 52 & 4,1731 & 202 \\
\hline & Erkek & 48 & 3,8958 & \\
\hline \multirow[t]{2}{*}{ Soru 2} & $\mathrm{~K} ı \mathrm{Z}$ & 52 & 4,0385 & 986 \\
\hline & Erkek & 47 & 4,0426 & \\
\hline \multirow[t]{2}{*}{ Soru 3} & $\mathrm{~K} ı \mathrm{Z}$ & 52 & 3,8462 & 495 \\
\hline & Erkek & 48 & 3,6875 & \\
\hline \multirow[t]{2}{*}{ Soru 4} & $\mathrm{~K} ı \mathrm{Z}$ & 52 & 3,7885 & 943 \\
\hline & Erkek & 48 & 3,7708 & \\
\hline \multirow[t]{2}{*}{ Soru 5} & $\mathrm{~K} \mathrm{IZ}$ & 52 & 3,7885 & ,866 \\
\hline & Erkek & 47 & 3,8298 & \\
\hline \multirow[t]{2}{*}{ Soru 6} & $\mathrm{~K} ı \mathrm{Z}$ & 52 & 3,5000 & ,540 \\
\hline & Erkek & 48 & 3,3333 & \\
\hline \multirow{2}{*}{ Soru 7} & $\mathrm{~K} ı \mathrm{Z}$ & 52 & 3,6923 & ,000 \\
\hline & Erkek & 48 & 2,6250 & \\
\hline \multirow[t]{2}{*}{ Soru 8} & $\mathrm{~K} ı \mathrm{Z}$ & 51 & 3,7843 & ,058 \\
\hline & Erkek & 48 & 3,2500 & \\
\hline \multirow[t]{2}{*}{ Soru 9} & $\mathrm{~K} \mathrm{IZ}$ & 52 & 3,0577 & ,681 \\
\hline & Erkek & 48 & 3,1875 & \\
\hline \multirow[t]{2}{*}{ Soru 10} & $\mathrm{~K} ı \mathrm{Z}$ & 52 & 2,9808 & 369 \\
\hline & Erkek & 48 & 2,7292 & \\
\hline \multirow[t]{2}{*}{ Soru 11} & $\mathrm{~K} ı \mathrm{Z}$ & 51 & 2,7255 & ,892 \\
\hline & Erkek & 47 & 2,7660 & \\
\hline \multirow[t]{2}{*}{ Soru 12} & $\mathrm{~K} ı \mathrm{z}$ & 52 & 3,0385 & ,650 \\
\hline & Erkek & 47 & 2,8936 & \\
\hline \multirow[t]{2}{*}{ Soru 13} & Kız & 52 & 3,1538 & 383, \\
\hline & Erkek & 48 & 3,3958 & \\
\hline \multirow[t]{2}{*}{ Soru 14} & $\mathrm{~K} \mathrm{IZ}$ & 52 & 3,7885 & ,990 \\
\hline & Erkek & 48 & 3,7917 & \\
\hline \multirow[t]{2}{*}{ Soru 15} & $\mathrm{~K} ı \mathrm{Z}$ & 52 & 3,9231 & 951 \\
\hline & Erkek & 48 & 3,9375 & \\
\hline \multirow[t]{2}{*}{ Soru 16} & Kız & 52 & 4,1538 & ,830 \\
\hline & Erkek & 48 & 4,2083 & \\
\hline \multirow[t]{2}{*}{ Soru 17} & $\mathrm{~K} ı \mathrm{z}$ & 52 & 3,9423 & ,057 \\
\hline & Erkek & 48 & 3,5000 & \\
\hline \multirow[t]{2}{*}{ Soru 18} & Kız & 52 & 3,8846 & ,573 \\
\hline & Erkek & 48 & 3,7500 & \\
\hline \multirow[t]{2}{*}{ Soru 19} & $\mathrm{~K} ı \mathrm{Z}$ & 52 & 4,0192 & ,009 \\
\hline & Erkek & 48 & 3,4167 & \\
\hline \multirow[t]{2}{*}{ Soru 20} & $\mathrm{~K} ı \mathrm{Z}$ & 52 & 3,5769 & ,044 \\
\hline & Erkek & 48 & 3,0625 & \\
\hline
\end{tabular}

Yedinci sorudaki "Türkçe derslerinde okuduğumuz veya dinlediğimiz bir metindeki bilinmeyen kelimelerle ilgili yazı yazdığımda (kompozisyon, şiir vb.) daha iyi öğreniyorum." ifadesi incelendiğinde 
gruplar arasında anlamlı farklılık olduğu görülmektedir. Kız öğrencilerin cevaplarının ortalaması 3,69, erkek öğrencilerin cevaplarının ortalaması ise 2,62 olarak tespit edilmiştir. Bu ortalamalar arasındaki farkın istatistiksel olarak anlamlı olup olmadığı bağımsız örneklemler için t testi kullanılarak yoklanmıştır. Elde edilen değerin 0,05 düzeyinde anlamlı olduğu görülmüştür $(p<0,05)$. Bu verilere göre kız öğrencilerin yeni öğrenilen kelimelerin yazılı anlatımda kullanıldığında daha iyi öğrenildiğine yönelik cevaplarının ortalamasının, erkek öğrencilerin cevaplarının ortalamasına göre daha yüksek olduğu görülmektedir.

On dokuzuncu sorudaki "Türkçe derslerinde okuduğumuz veya dinlediğimiz metinler aracılı̆̆ıyla öğrendiğim kelimeleri günlük yaşantımda genellikle ben de kullanmaya çalışırım." ifadesi incelendiğinde gruplar arasında anlamlı farklılık olduğu görülmektedir. Kız öğrencilerin cevaplarının ortalaması 4,01, erkek öğrencilerin cevaplarının ortalaması ise 3,41 olarak tespit edilmiştir. Bu ortalamalar arasındaki farkın istatistiksel olarak anlamlı olup olmadığı bağımsız örneklemler için t testi kullanılarak yoklanmıştır. Elde edilen değerin 0,05 düzeyinde anlamlı olduğu görülmüştür $(p<0,05)$. Bu verilere göre kız öğrencilerin erkek öğrencilere göre yeni öğrenilen kelimeleri günlük yaşantılarında daha çok kullandıklarını ifade ettikleri söylenilebilir.

Yirminci sorudaki "Türkçe derslerinde okuduğumuz veya dinlediğimiz metinlerdeki bilinmeyen kelimelere yönelik ders kitaplarındaki etkinliklerin yeterli olduğunu düşünüyorum." ifadesi incelendiğinde gruplar arasında anlamlı farklılık olduğu görülmektedir. Kız öğrencilerin cevaplarının ortalaması 3,57, erkek öğrencilerin cevaplarının ortalaması ise 3,06 olarak tespit edilmiştir. Bu ortalamalar arasındaki farkın istatistiksel olarak anlamlı olup olmadığı bağımsız örneklemler için t testi kullanılarak yoklanmıştır. Elde edilen değerin 0,05 düzeyinde anlamlı olduğu görülmüştür $(p<0,05)$. Bu verilere göre kız öğrencilerin ders kitaplarındaki bilinmeyen kelimelere yönelik etkinlikleri erkek öğrencilere göre daha yeterli gördükleri söylenebilir.

\section{Açık uçlu görüşme formlarında yer alan verilerin değerlendirilmesi}

Bu araştırma sürecinde kullanılan açık uçlu görüşme formunda yer alan ilk soru "Size göre Türkçe derslerinde metinlerde yer alan bilinmeyen kelimeleri öğrenmek için en iyi yöntem ne olabilir? Açıklayınız." şeklindedir. Araştırmaya katılan öğrencilerin cevapları incelendiğinde frekansı en yüksek uygulamanın "bilinmeyen kelimenin tahmin edilerek tahminlerin sözlük ile karşılaştırılması" olduğu görülmüştür $(F: 9)$. Bu durumun sebebinin ders kitaplarındaki bilinmeyen kelimelere yönelik etkinliklerin, "T.6.3.5.; T.7.3.5. Bağlamdan hareketle bilmediği kelime ve kelime gruplarının anlamını tahmin eder." (MEB, 2019: 40-44) kazanımı doğrultusunda tasarlanmasından kaynaklı olduğu düşünülmektedir. Bu doğrultuda öğrencilerin ders kitaplarındaki mevcut bu yöntemi etkili buldukları söylenilebilir. Bilinmeyen kelimenin cümle içerisinde kullanılması ( $F: 4)$ uygulaması ise araştırmaya katılan öğrencilerin en çok dikkat çektikleri ikinci alandır. Öğrencilerin bilinmeyen kelimelerin öğretiminde dikkat çektikleri diğer alanlar ise bilinmeyen kelimelere yönelik sözlük oluşturmak (F:3), tekrar etmek (F:1), eşleştirme yapmak (F:1), öğretmene sormak ( $F: 1)$ ve etkinlik temelli ders işlemek $(F: 1)$ şeklindedir.

Görüşme formunda yer alan ikinci soru "Türkçe derslerinde okuduğunuz veya dinlediğiniz metinler aracılığıyla öğrendiğiniz kelimeleri diğer derslerinizde de kullandınız mı? Cevabınız evet ise hangi dersler olduğunu açıklayınız?" şeklindedir. Araştırmaya katılan öğrencilerin cevapları incelendiğinde 15 (\% 75) öğrencinin yeni öğrendiği kelimeleri diğer derslerde kullandıkları, 5 (\% 25) öğrencinin ise kullanmadıkları yönünde cevap verdikleri görülmüştür. Cevaplar incelendiğinde yeni öğrenilen kelimelerin kullanımı açısından en çok değinilen ders "sosyal bilgilerdir" (F:12). "Fen bilgisi" ve "hepsi" ise cevaplar incelendiğinde en çok değinilen ikinci alanlardır (F:4). íki öğrencinin ise yeni öğrendikleri kelimeleri matematik dersinde kullandıklarını belirttikleri görülmüştür (F:2).

Görüşme formunda yer alan üçüncü soru "Türkçe derslerinde okuduğunuz veya dinlediğiniz metinler aracılığıyla öğrendiğiniz kelimeler günlük yaşantınızda size katkı sağladı mı? Açıklayınız." şeklindedir. Araştırmaya katılan öğrencilerin tamamının olumlu yönde cevap verdikleri görülmüştür (F:20). Bu soruda en çok değinilen alan "günlük hayatta kendini ifade etmeye katkı sağlamasıdır" (F:15). "Kitap okurken yardımcı olması" ve "sınavda yardımcı olması" ise birer öğrenci tarafından belirtilmiştir (F:1). 3 öğrenci ise sadece "evet" şeklinde cevap vermiştir. Bu durum özellikle bilinmeyen kelimelerin 
öğretiminde günlük yaşamla bağ kurulması gerekliliği ve kendini ifade etmedeki niteliğini göstermesi açısından önemlidir.

Görüşme formunda yer alan son soru "Türkçe derslerinde iyi öğrendiğinizi düşündüğünüz kelimelerle ilgili derslerde hangi türden etkinlikleri yaptığınızı hatırlıyorsanız açıklayınız." şeklindedir. Araştırmaya katılan öğrencilerin cevapları incelendiğinde "bilinmeyen kelimenin tahmin edilerek tahminlerin sözlük ile karşılaştırılması" en çok değinilen etkinliktir (F:7). Bu durum birinci sorudaki sonuçları destekler niteliktedir. Bilinmeyen kelimelere yönelik diğer etkinlikler ise "bulmaca çözme" $(F: 3)$, "cümle içinde kullanma" (F:3), "eşleştirme yapma" (F:2), "oyunlaştırma" (F:1), "sözlük oluşturma" (F:1), "diğer derslerde kullanılma durumu" (F:1) şeklindedir. 2 öğrencinin ise bu soruya "hatırlamıyorum" şeklinde cevap verdikleri görülmüştür.

\section{Tartışma ve Sonuç}

Bu araştırma sürecinde uygulanan likert tipi tutum ölçeği ve açık uçlu görüşme formlarından elde edilen veriler vasıtasıyla ulaşılan sonuçlar şu şekilde sıralanabilir:

- Ortaokul öğrencilerine yapılan bu araştırmanın sonuçlarına göre, arasstırmaya katılan öğrencilerin genelinin bilinmeyen kelimelerin öğretimi süreçlerinde eşleştirme, bulmaca türünden etkinlikler vasıtasıyla daha iyi öğrendiklerini ifade ettikleri görülmüştür.

- Öğrencilerin çoğunluğunun bilinmeyen kelimelerin öğretimi süreçlerinde sözlük kullanımı, tahminlerin sözlükten kontrol edilmesi, kelimenin manasının öğretmene sorulması, oyunlaştırma ile öğretme gibi uygulamaları destekledikleri sonucuna ulaşılmıştır. Bu duruma ek olarak yedinci sınıf öğrencilerinin bilinmeyen kelimelerin öğretiminde oyunlaştırmanın kullanılması yöntemini altıncı sınıf öğrencilerine göre daha çok onayladıkları tespit edilmiştir.

- Öğrencilerin çoğunluğunun yeni öğrenilen kelimelerin sözlü anlatım etkinliklerinde kullanıldığında daha iyi öğrendiklerini belirttikleri tespit edilmiştir. Araştırmaya katılan öğrencilerin arasında bilinmeyen kelimelerin öğretiminde kelimelerin yazma etkinlikleri sırasında kullanılması şeklindeki uygulamaları olumlu olarak değerlendirenlerin sayısının diğer gruba göre fazla olduğu görülmüştür. Bu sonuca ek olarak kız öğrencilerin yeni öğrenilen kelimelerin yazılı anlatımda kullanıldığında daha iyi öğrenildiğine yönelik cevaplarının ortalamasının, erkek öğrencilerin cevaplarının ortalamasına göre daha yüksek olduğu sonucuna ulaşılmıştır.

- Yeni öğrenilen kelimelerin kaydedildiği sözlüğü olan öğrencilerle olmayan öğrencilerin sayının birbirine yakın oranda olduğu görülmüştür. Ayrıca bu kelimelerin sözlüğe kaydedilmesi aşamasında da ilgi çekicilik, ileride kullanabilme gibi özelliklerin çok etkili olmadığı sonucuna ulaşılmıştır. İlgili maddeler sınıf düzeyleri açısından değerlendirildiğinde, altıncı sınıf öğrencilerinin bilinmeyen kelimelerin öğretiminde sözlük oluşturma yöntemini yedinci sınıf öğrencilerine göre daha çok kullandıkları tespit edilmiştir. Bu sonuca ek olarak altıncı sınıf öğrencilerinin yeni öğrenilen kelimelerin bütününü sözlüklerine kaydetme yönünden yedinci sınıf öğrencilerine göre ortalamalarının daha fazla olduğu görülmüştür.

- Öğrencilerin çoğunluğunun yeni öğrenilen kelimelerle Türkçe derslerindeki farklı metinlerde, diğer derslerde (sosyal bilgiler, fen bilgisi, matematik vb.), günlük yaşantılarında karşılaştıklarını ve bu kelimeleri diğer derslerde kullandıklarını belirttikleri görülmüştür. Açık uçlu görüşme formlarında da öğrencilerin çoğunluğunun bu yönde cevap verdikleri ve bu kelimelerle en çok sosyal bilgiler derslerinde karşılaştıklarını belirttikleri tespit edilmiştir. Ayrıca bu kelimelerin sözcük hazinelerinin gelişimine katkı sağladığı ve bu kelimeleri günlük yaşantılarında da kullandıkları, öğrencilerin çoğunluğu tarafından belirtilmiştir. İlgili maddeler sınıf düzeyleri açısından değerlendirildiğinde yedinci sınıf öğrencilerinin altıncı sınıf öğrencilerine göre yeni öğrendikleri kelimeleri günlük yaşantılarında daha fazla kullandıklarını ifade ettikleri tespit edilmiştir. Kız öğrencilerin ise erkek öğrencilere göre yeni öğrenilen kelimeleri günlük yaşantılarında daha çok kullandıklarını belirttikleri görülmüştür.

- Açık uçlu görüşme formlarına cevap veren öğrencilerin tamamının derslerde bilinmeyen kelimelere yönelik etkinliklerde öğrenilen kelimelerin günlük yaşantılarında kendilerini ifade etme becerilerine katkı sağladığını belirttikleri sonucuna ulaşılmıştır. 
- Öğrencilerin çoğunluğunun ders kitaplarındaki bilinmeyen kelimelere yönelik etkinlikleri yeterli buldukları sonucuna ulaşılmıştır. Bu sonuca ek olarak kız öğrencilerin ders kitaplarındaki bilinmeyen kelimelere yönelik etkinlikleri erkek öğrencilere göre daha yeterli gördükleri sonucuna ulaşılmıştır.

- Görüşme formlarındaki verilerden hareketle öğrencilerin çoğunluğu, bilinmeyen kelimelerin öğretiminde en etkili yöntemin "bilinmeyen kelimenin tahmin edilerek tahminlerin sözlük ile karşılaştırılması" olduğunu ifade etmişlerdir.

Konu alanı ile ilgili çalışmalar incelendiğinde okunan metnin doğru anlaşılmasında kelime bilgisinin önemli olduğu görülmektedir. Ehri (1987: 28) çocukların ilk okuma süreçlerinde nasıl öğrendiklerinin anlaşımasının yalnızca dil becerileri ve okul başarı açısından değil, bilgiyi işleme süreçleri açısından da önemli olduğunu belirtir. Bu durumun daha yüksek sınıf seviyelerindeki yansımalarından birinin de okuma sırasında kelimelerin anlamlarının hatırlanması olduğu söylenebilir. Çünkü okuma önemli bir anlama aracıdır. Bu süreçte doğru anlamanın sağlanabilmesi için metinde yer alan kelimelerin doğru algılanması ve anlaşılması da gerekir. Bu açıdan bilinmeyen kelimelerin öğretiminin dil öğretim süreçlerinde önemli rolünün olduğu düşünülmektedir. Akyol ve Temur (2007: 197) okuma becerilerinin gelişimi ile kelime hazinesinin gelişimi arasında bağ kurar. Bu bağın "kelime hazinesinin zenginliği ile okuma başarısı arasında olumlu yönde" olduğu belirtir (Akyol ve Temur, 2007: 200). Akyol ve Temur (2007: 206) "kelime öğretiminde en etkili yolun anlamlı çalışmalar yapmak" olduğunu ifade eder ve bu türden çalışmaların öğrenciyi düşünmeye, "tecrübelerini kullanmaya" sevk ettiğini belirtir. Bu doğrultuda araştırma vasıtasıyla öğrencilerden elde edilen verilerden hareketle bilinmeyen kelimelerin öğretiminde yapılan uygulamaların olumlu olduğu söylenebilir. Çünkü hem tutum ölçeği hem de açık uçlu görüşme formları vasıtasıyla araştırmaya katılan öğrencilerin verdikleri cevaplar incelendiğinde bilinmeyen kelimelerin öğretiminde uygulanan yöntemlerin öğrencilerin geneli tarafından olumlu olarak nitelendirildiği görülmüştür. Bu durumun derslerde ilgili kazanımlar ve ders kitaplarının da bu doğrultuda hazırlanması sonucunda öğretmenlerin uygulamaları ile bağlantısının olduğu düşünülmektedir. Nitekim öğrencilerin bilinmeyen kelimelerin öğretim süreçlerinde etkili olduğunu bildirdikleri bilinmeyen kelimenin bağlamdan yararlanılarak tahmin edilmesi ve tahminlerin sözlük ile karşılaştırılması uygulamasının Türkçe Öğretim Programı'ndaki “T.6.3.5.; T.7.3.5." (MEB, 2019: 40-44) nolu kazanımlarla uyumlu olduğu görülmektedir. Bağlamdan yararlanarak kelime öğretimine yönelik araştırmalar bu konunun önemine değinmektedir. Nagy, Herman ve Anderson (1985: 252) kelime öğretiminde yazılı bağlamları inceledikleri araştırmalarında, sözlü bağlamlara da vurguda bulunurlar ve bunların kelime dağarcığının zenginleşmesinde önemli rolünün olduğunu aktarırlar. Na ve Nation (1985: 39) güçlü bir strateji olarak niteledikleri bağlamdan yararlanarak tahmin etme becerisinin gelişmesi durumunda öğrencilerin karşılaştıkları birçok kelimeyi yüksek oranda (\% 85) tahmin edebileceklerini ifade eder.

Bu araştırmada "T.6.3.5.; T.7.3.5." nolu kazanımlar açısından dikkat çeken bir diğer konu ise yeni öğrenilen kelimelere yönelik sözlük oluşturma etkinliğidir. Bu konuya yönelik sorulardan hareketle sözlük oluşturma etkinliğini uygulama/uygulamama açısından öğrencilerin benzer oranda cevap verdikleri görülmüştür. Ancak ilgili kazanımlarda "Öğrencinin öğrendiği kelime ve kelime gruplarından sözlük oluşturması teşvik edilir." (MEB, 2019: 40-44) şeklindeki açıklama ile sözlük oluşturma uygulamasına vurgu yapıldığı görülmektedir. Bu konuyla bağlantılı olarak Maden ve Demir (2019: 433) sözlük kullanma yönünden olumlu tutum kazanılması için etkinlikler tasarlanması ve öğretmenin model olması gerektiğini ifade ederler. Bu doğrultuda öğrencileri yeni öğrendikleri kelimelere yönelik sözlük oluşturmalarına teşvik etmek amaçlı öğretmenlerin çeşitli etkinlikler vasıtasıyla yönlendirmelerde bulunmaları önerilmektedir.

Türkçe Öğretim Programı'nda öğretim süreçleri vasıtasıyla öğrencilerin hayata hazırlanmaları konusuna özellikle vurgu yapılır (MEB, 2019: 3). Ana dili öğretim süreçlerinin öğrencilerin yaşantılarına çok boyutlu olarak yansıması, bu sürece etkide bulunan değişkenlerin de çok boyutlu olarak ele alınmasını gerektirmektedir. Bu durum kelime öğretim süreçlerini de içerisinde barındırır. Okur ve Dağtaş (2014: 78) Türkçe eğitiminde kelime öğretimi alanında yapılan çalışmaları inceler ve "yaş, cinsiyet, akademik başarı, yerleşke türü, elektronik ortam" gibi değişkenlerin kelime öğretimindeki rolüne yönelik araştırmaların yetersiz olduğunu, bu alanlara yönelik araştırmaların yapılması gerekliliğine dikkat çeker. Bu araştırmada bilinmeyen kelimelerin öğretim süreçlerinde sınıf ve cinsiyet 
değişkenleri açısından öğrencilerin görüşleri değerlendirilmiştir. Bu değerlendirmeler vasıtasıyla özellikle yeni öğrenilen kelimelerin günlük yaşantıda kullanılmasında yaş ve cinsiyet değişkenlerinin etkili olduğu görülmüştür. Çünkü araştırma sonuçlarına göre yeni öğrenilen kelimelerin günlük yaşantılarında kız öğrenciler erkek öğrencilere göre; yedinci sınıflar ise altıncı sınıflara göre daha fazla kullandıklarını ifade etmişlerdir. Yeni öğrenilen kelimelerin pasif konumdan aktif konuma geçmesinde günlük yaşantıda kullanılmasının etkili rolü vardır (Göçer, 2009: 1028). Bu doğrultuda diğer öğrencilerin de kelimeleri günlük yaşantılarına aktarmalarına imkân sağlayacak etkinliklerin tasarlanmasının öğretim amaçlarına ulaşılması açısından katkısının olacağı düşünülmektedir. Ayrıca bu sonuca ek olarak kız öğrencilerin erkek öğrencilere göre yeni öğrenilen kelimelerin yazıı anlatımda kullanıldığında daha iyi kavrandığını ifade ettikleri görülmüştür. Bu konuyla ilgili olarak Göçer (2018: 123) kelime öğretiminde, kelimelerin iyi bir şekilde kavranıp zihne kaydedilmesi gerektiğini belirtir ve bu kelimelerin de öğrencilerin kendilerini ifade etme süreçlerinde kullanmalarının önemine değinir. Bu durumun sağlanmasında da yeni öğrenilen kelimelere yönelik konuşma ve yazma etkinliklerinin etkili olacağını ifade eder (Göçer, 2018: 123). Bu doğrultuda gerekli durumlarda ek uygulamalarla öğrencilerin bu becerilerinin desteklenmesi önerilmektedir.

\section{Araştırma ve Yayın Etiği}

Bu çalışmada "Yükseköğretim Kurumları Bilimsel Araştırma ve Yayın Etiği Yönergesi" kapsamında uyulması belirtilen tüm kurallara uyulmuştur. Yönergenin ikinci bölümü olan "Bilimsel Araştırma ve Yayın Etiğine Aykırı Eylemler" başlığı altında belirtilen eylemlerden hiçbiri gerçekleştirilmemiştir.

\section{Etik Kurul izni}

Kurul adı = Kayseri İ Milli Eğitim Müdürlüğü

Karar tarihi $=13.08 .2020$

Belge sayı numarası 10587341

\section{Yazarların Katkı Oranı}

Bu araştırmaya genel olarak 1. yazar \% 60, 2. Yazar ise $\% 40$ oranında katkı sağlamıştır.

\section{Çıkar Çatışması}

Bu araştırmada çıkar çatışması teşkil edebilecek herhangi bir durumun bulunmadığı yazarlar tarafından beyan edilmektedir.

\section{Kaynaklar}

Ak, B. (2010). Parametrik hipotez testleri. Ş. Kalaycı (Ed.), Spss uygulamalı çok değişkenli istatistik teknikleri içinde (s. 73-82). Ankara: Asil Yayın Dağıtım.

Aktaş, Ş., Gündüz, O. (2017). Yazılı ve sözlü anlatım okuma-dinleme-konuşma-yazma. Ankara: Akçağ Yayınları.

Akyol, H., Temur, T. (2007). Kelime hazinesinin geliştirilmesi. A. Kırkkılıç, H. Akyol (Ed.), ilköğretimde Türkçe öğretimi içinde (s. 195-232). Ankara: Pegem A Yayıncılık.

Akyüz Aru, S. ve Ertem, ì. S. (2014). Türkçe ders kitaplarında kelime hazinesini geliştirmeye yönelik planlamanın incelenmesi. Turkish Studies, 9(3), 575-694.

Bademci, V. (2006). Tartışmayı sonlandırmak: Cronbach'ın Alfa Katsayısı, iki değerli $(0,1)$ ölçümlenmiş maddeler ile kullanılabilir. Kazım Karabekir Eğitim Fakültesi Dergisi, 13, 438-446.

Biçer, N. ve Polatcan, F. (2015). Yabancı dil olarak Türkçe öğretiminde kelime öğrenme stratejilerinin değerlendirilmesi. Atatürk Üniversitesi Türkiyat Araştırmaları Enstitüsü Dergisi, 54, 811-828.

Büker, M. ve Zeytinkaya, D. (2013). Eş anlamlı ve zıt anlamlı kelime öğretiminin dil edinimindeki yeri ve önemi. Turkish Studies, 8(10), 185-191.

Büyüköztürk, Ş., Kılıç Çakmak, E., Akgün, Ö. E., Karadeniz, Ş., Demirel, F. (2019). Eğitimde bilimsel araştırma yöntemleri. Ankara: Pegem Akademi. 
Bilinmeyen Kelimelerin Öğretiminde Kullanılan Yöntemlerin Etkililiğinin Öğrencilerin Görüşleri Vasıtasıyla Değerlendirilmesi

Çapraz Baran, Ş., Diren, E. (2019). Ortaokul ve imam hatip ortaokulu Türkçe 5. sınıf ders kitabı. Ankara: Anıttepe Yayıncılık.

Demirel, T. (2019). Ortaokul ve imam hatip ortaokulu Türkçe 6. sınıf ders kitabı. Ankara: Ekoyay Yayıncılık.

Duran, E. ve Bitir, T. (2017). Bağlam temelli kelime öğretiminin kelime kazanımına katkısı. Uluslararası Eğitim Bilimleri Dergisi, 4(11), 70-94.

Ehri, L. C. (1987). Learning to read and spell words. Journal of Reading Behavior, XIV (1), 5-31.

Erdem, A. R. (2005). Öğrenmede etkili yollar: öğrenme stratejileri ve öğretimi. ilköğretim-Online, 4(1), 1-6.

Göçer, A. (2009). Türkçe eğitiminde öğrencilerin söz varlığını geliştirme etkinlikleri ve sözlük kullanımı. Turkish Studies, 4(4), 1025-1055.

Göçer, A. (2018). Metin işleme süreçli - mikro öğretim uygulama örnekli Türkçe öğrenme ve öğretim yaklaşımları. Ankara: Pegem Akademi Yayıncılık.

Hsueh-chao, M. H. and Nation, P. (2000). Unknown vocabulary density and reading comprehension. Reading in a Foreing Languagae, 13(1), 403-430.

İler, İ. (2014). Kelime öğretiminde grafik düzenleyicileri (frayer modeli örneği). Turkish Studies, 9(3), 755-770.

Kalaycı, Ş. (2010). Faktör analizi. Ş. Kalaycı (Ed.), Spss uygulamalı çok değişkenli istatistik teknikleri içinde (s. 321-331). Ankara: Asil Yayın Dağıtım.

Kansızoğlu, H. B. (2017). Kelime öğretim yöntemlerinin kelime hazinesinin gelişimindeki etkisinin karşılaştırılması: meta analitik bir değerlendirme. International Online Journal of Educational Sciences, 9(3), $821-841$.

Karadağ, Ö. ve Kurudayıoğlu, M. (2010). 2005 Türkçe programına göre hazırlanmış ilköğretim birinci kademe Türkçe ders kitaplarının kelime hazinesi. TÜBAR, XXVII, 423-436.

Kayış, A. (2010). Güvenilirlik analizi. Ş. Kalaycı (Ed.), Spss uygulamalı çok değişkenli istatistik teknikleri içinde (s. 403-419). Ankara: Asil Yayın Dağıtım.

Kula Kartal, S. ve Mor Dirlik, E. (2016). Geçerlik kavramının tarihsel gelişimi ve güvenirlikte en çok tercih edilen yöntem: Cronbach Alfa Katsayısı. Abant İzzet Baysal Üniversitesi Eğitim Fakültesi Dergisi, 16(4), 1865-1879.

Maden, S. ve Demir, R. (2019). Ortaokul Türkçe dersi öğretim programlarında sözlük kullanma alışkanlığı kazandırmaya dair tespitler. Mersin Üniversitesi Eğitim Fakültesi Dergisi, 15(2), 419436.

MEB. (2019). Türkçe dersi öğretim programı. MEB Yayınları. Erişim adresi: http://mufredat.meb.gov.tr/Dosyalar/20195716392253-02-

T\%C3\%BCrk\%C3\%A7e\%20\%C3\%96\%C4\%9Fretim\%20Program\%C4\%B1\%202019.pdf

Memiş, M. R. (2019a). Kelime öğretim stratejileri ölçeği: geliştirme, geçerlik ve güvenirlik çalışması. Turkish Studies, 14(4), 2579-2593.

Memiş, M. R. (2019b). Yabancılara Türkçe öğretenlerin başvurdukları kelime öğretim stratejilerinin belirlenmesi. Bayburt Eğitim Fakültesi Dergisi, 14(28), 275-300.

$\mathrm{Na}$, L. and Nation, I.S.P. (1985). Factors affecting guessing vocabulary in context. RELC Journal, 16 (1), 33-42.

Nagy, W., Herman, P. and Anderson, R. (1985). Learning words from context. Reading Research Quarterly, 20(2), 233-253.

Okur, A. ve Dağtaş, A. (2014). Ortaokula yönelik kelime öğretimi çalışmaları. Ana Dili Eğitimi Dergisi, 2(4), 66-84.

Özbay, M. ve Melanlığlu, D. (2008a). Türkçe eğitiminde kelime hazinesinin önemi. Yüzüncü Yıl Üniversitesi Eğitim Fakültesi Dergisi, 5(1), 30-45.

Özbay, M. ve Melanlıoğlu, D. (2008b). Kelime öğretiminde örneklemenin önemi ve Divanü Lügat-it Türk. Mustafa Kemal Üniversitesi Sosyal Bilimler Enstitüsü Dergisi, 5(10), 49-58.

Yıldırım, A., Şimşek, H. (2008). Sosyal bilimlerde nitel araştırma yöntemleri. Ankara: Seçkin Yayıncılık.

Yılmaz, M. (2008). Kelime tekrar tekniğinin akıcı okuma becerilerini geliştirmeye etkisi. Türk Eğitim Bilimleri Dergisi, 6(2), 323-350. 


\section{Introduction}

\section{Extended Abstract}

It is seen that there are two main educational processes in vocabulary teaching: mother tongue education and foreign language education. This situation may require teachers to use different methods in terms of the skills that are aimed to be acquired by students as a result of educational processes. As a matter of fact, besides measurement and evaluation, teaching methods, tools and equipment, etc. diversity in aspects is one of the main approaches of the programs (MEB, 2019: 6). In providing diversity in subjects such as teaching methods and assessment and evaluation activities, it is necessary to consider the interests, needs and readiness of the students, the characteristics of the class, and the learning outcomes of the course. In this direction, teachers have an important responsibility in terms of originality and creativity in the design of the education processes (MEB, 2019: $6)$.

Mother tongue teaching processes play an important role in the development of individuals' language skills as well as their academic skills. Because the skill of reading along with listening / watching is effective in individuals' perception / understanding of events and concepts. For this reason, this multidimensional structure of mother tongue education should be taken into consideration. In this respect, it can be said that the development of comprehension skills is proportional to the vocabulary of individuals. Because of this important feature of vocabulary, researchers draw attention to issues such as the necessity of a logical framework in the teaching of words and the necessity to focus on the meaning properties of words (Özbay, Melanlıoğlu, 2008a: 42).

\section{Method}

The aim of this research is to evaluate the effectiveness of the methods used in teaching unknown words in Turkish lessons. For this purpose, it was planned to determine the attitudes of middle school students towards activities related to unknown words in Turkish lessons and to receive their opinions on this issue. One of the quantitative methods, the scanning model was used in this study in which mixed method was used. The study group of this research is composed of secondary school students. The random sampling method was used in the selection of the sample in the study. The voluntary principle was taken as basis for the participation of the students in the research. By making detailed explanations about the research, it was stated in writing that the students would not participate in the study if they wanted and even if they did, they could leave the study at any time. In the research, attitude scale and standardized open-ended interview form were used. 100 students participated in the research conducted with the attitude scale and 20 students participated in the research conducted with open-ended interviews.

In the research, quantitative and qualitative research methods were used together. Likert type attitude scale was used to determine the students' attitudes towards the methods used in teaching unknown words in Turkish lessons. A total of 100 students answered the items in this scale. The data of this scale were analyzed with Spss 20 program. The answers given to the items in the scale were analyzed in terms of percentages. In addition, it was also examined whether the answers given to the questions made a difference in terms of grade level and gender. A total of 20 students answered the questions in the standardized open-ended interview form. Document analysis was used as a data collection method in the research.

\section{Result and Discussion}

According to the results of this study conducted with middle school students, it was seen that the students participating in the study generally stated that they learned better through matching and puzzle-type activities in the teaching of unknown words.

It was concluded that most of the students supported practices such as using dictionary in the teaching of unknown words, checking predictions from dictionary, asking the teacher the meaning of the word, and teaching with drama. In addition to this situation, it was determined that seventh grade students approved the method of using drama in teaching unknown words more than sixth grade students. 
It was determined that the majority of the students stated that they learned better when the newly learned words were used in verbal expression activities. Among the students who participated in the study, the number of those who positively evaluated the practice of using words during writing activities in the teaching of unknown words was higher than in the other group. In addition to this result, it was observed that female students stated that newly learned words were learned better when used in written expression than male students.

It was observed that the number of students who had a dictionary in which newly learned words were recorded and those who did not were similar. In addition, it was concluded that during the recording of these words in the dictionary, features such as attract attention and future use are not very effective. When the relevant items were evaluated in terms of their grade levels, it was determined that sixth grade students used the dictionary creation method more than seventh grade students in teaching unknown words. In addition to this result, it was observed that the average of sixth grade students in terms of recording the whole of newly learned words in their dictionaries was higher than seventh grade students.

It was observed that the majority of the students stated that they encountered the newly learned words in different texts in Turkish lessons, in other lessons (social studies, science, mathematics), in their daily lives and used these words in other lessons. In open-ended interview forms, it was determined that the majority of students responded in this direction and stated that they mostly encountered these words in social studies lessons. In addition, it was stated by the majority of the students that these words contributed to the development of their vocabulary and they used these words in their daily lives. When the relevant items were evaluated in terms of their grade levels, it was determined that seventh grade students stated that they used more newly learned words in their daily lives compared to sixth graders. It was observed that female students stated that they used the newly learned words more in their daily lives than male students. It was concluded that all of the students who answered the open-ended interview forms stated that the words learned in the activities for unknown words in the lessons contribute to their ability to express themselves in their daily lives. 